DNA Libraryof Life, research article

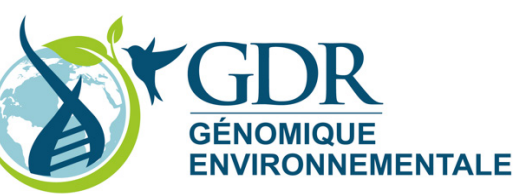

urn:1sid:zoobank.org:pub:2FE169D8-BA25-4561-A7B8-66AA0563E1A9

\title{
Genetic and morphological evidence for cryptic species in Macrobrachium australe and resurrection of M. ustulatum (Crustacea, Palaemonidae)
}

\author{
Magalie CASTELIN ${ }^{1, *}$, Valentin de MAZANCOURT ${ }^{2}$, Gérard MARQUET ${ }^{3}$, \\ Gabrielle ZIMMERMAN ${ }^{4}$ \& Philippe KEITH $^{5}$ \\ 1,2,3,4,5 Muséum national d'Histoire naturelle, DMPA, UMR 7208, CP 26, 57 rue Cuvier, \\ 75231 Paris Cedex 05, France. \\ ${ }^{1}$ Aquatic Animal Health Section, Fisheries and Oceans Canada, Pacific Biological Station, \\ 3190 Hammond Bay Road, Nanaimo, British Columbia, Canada V9T 6N7. \\ ${ }^{*}$ Corresponding author: magalie.castelin@gmail.com \\ ${ }^{2}$ Email: valentin.demazancourt@laposte.net \\ ${ }^{3}$ Email: gmarquet@neuf.fr \\ ${ }^{4}$ Email: zimmermann@mnhn.fr \\ ${ }^{5}$ Email: keith@mnhn.fr \\ ${ }^{1}$ urn:1sid:zoobank.org:author:9464EC90-738D-4795-AAD2-9C6D0FA2F29D
${ }^{2}$ urn:1sid:zoobank.org:author:334E54F3-9FE1-4208-8861-1946579697A5
${ }^{3}$ urn:1sid:zoobank.org:author:BB110358-4FA2-4F5B-BF3A-B51F69D81AA9
${ }^{4}$ urn:1sid:zoobank.org:author:35ADE4FB-7098-4E48-9075-584D65019B51
${ }^{5}$ urn:1sid:zoobank.org:author:D7E2BEDC-B068-4AE5-A168-AAC1E3CA7F09
}

Abstract. Macrobrachium australe is an amphidromous prawn living in the insular freshwater systems of the Indo-Pacific. Because it possesses few informative morphological characters, that often vary from one habitat to another, $M$. australe has produced much taxonomic confusion and has historically been described under eight synonyms. Here, 53 specimens collected throughout the Indo-Pacific under the name $M$. australe were phylogenetically and morphologically examined. Results revealed that what has been called $M$. australe belongs to at least two distinct species: $M$. australe, distributed from the Southwest Indian Ocean to the Central Pacific Ocean, and a cryptic species potentially restricted to the Northwest Pacific Ocean, here identified as M. ustulatum, which until now was considered as a junior synonym. Although they are not quite found in the same habitat (lentic-lotic), the presence of these distinct, and reciprocally monophyletic entities in the same rivers on the islands of Palau and Santo strongly favors the hypothesis of two reproductively isolated entities. Six morphological characters, including the proportions of the joints of the male second pereiopod, the shape of the epistome lobe and the armature of the fourth thoracic sternite, are evidenced as diagnostic. A neotype of M. australe is designated and deposited in the Muséum national d'Histoire naturelle in Paris.

Keywords. Amphidromous prawn, Indo-West Pacific, multi-locus phylogeny, morphology. 
Castelin M., de Mazancourt V., Marquet G., Zimmerman G. \& Keith P. 2017. Genetic and morphological evidence for cryptic species in Macrobrachium australe and resurrection of M. ustulatum (Crustacea, Palaemonidae). European Journal of Taxonomy 289: 1-27. https://doi.org/10.5852/ejt.2017.289

\section{Introduction}

Macrobrachium australe (Guérin-Méneville, 1838 in Guérin-Méneville 1829-1838) is a large-sized prawn species living in the insular freshwater systems of the tropical Indo-Pacific. The species possesses an amphidromous life cycle in which the larvae develop in the marine plankton before returning as juveniles to rivers to grow and reproduce. This specific life cycle is considered a critical element to the persistence of the populations and the viability of the species in insular freshwater habitats (Keith 2003), which are usually sparse and of an unstable nature. Macrobrachium australe, which is one of the most widespread amphidromous prawns, distributed from the Seychelles and Madagascar eastwards to French Polynesia, is considered as a "Least Concern" species in conservation priority (Jayachandran 2001). However, an unpublished primary molecular sequencing of specimens collected by the Muséum national d'Histoire naturelle (MNHN) over a range that spans the Indo-Pacific suggested the possible existence of distinct evolutionary units (species) within what was morphologically assigned to M. australe. This raised questions about the exact distribution of $M$. australe and its actual conservation status.

The genus Macrobrachium Spence Bate, 1868 is considered as one of the most challenging decapod crustacean groups for species delineation and alpha taxonomy (Holthuis 1950; Chace \& Bruce 1993; Short 2004). While taxonomically informative morphological traits (e.g., on the rostrum and the second pereiopods) are mostly present only in fully developed males, they also often vary within species (Holthuis 1950; Short 2004). Indeed, different environmental conditions have been shown to induce carapace shape variation in the South American prawn M. borellii (Nobili, 1896) (Torres et al. 2014) and the Asian prawn M. nipponense (De Haan, 1849 in De Haan 1833-1850) (Chen et al. 2015). Similarly, in populations of $M$. australe from Reunion Island, the rostral shape varies with water velocity, being long, thin and orientated upward in lentic populations and short, robust and straight in lotic populations (Zimmermann et al. 2012). Taking into account these data, it is likely that the carapace plasticity in Macrobrachium has contributed to taxonomic confusion. In this context, species delimitation in the genus should not be solely based on carapace features but on the integration of complementary sources of evidence (e.g., morphometric or molecular data).

Addressing these issues, however, requires a reasonably complete sampling size, ideally covering the whole distribution range of the target species. Indeed, the broad geographical distribution of M. australe, combined with the difficulty of accessing tropical insular freshwater systems, has led to geographic sampling gaps blurring the distinction between geographical and/or ecological variations and specieslevel divergences. As a consequence, $M$. australe has historically been described under eight synonyms (De Grave \& Fransen 2011), each more or less corresponding to an isolated location on the edge of the species range: 2 synonyms were described from the Central and Southwestern Pacific (Palaemon australis Guérin-Méneville, 1838 in Guérin-Méneville 1829-1838 from Tahiti and P. danae Heller, 1865 from Sydney, Australia (but probably erroneous, see Short 2004)); 3 synonyms were described from the Central Indo-Pacific (P. dispar von Martens, 1868 from Adonara Island, Indonesia; P. (Eupalaemon) ustulatus Nobili, 1899 from Rigo, Papua New Guinea; Leander lepidus de Man, 1915 from Jos Sudarso Bay, West Indonesian Papua); and 3 synonyms were described from the Western Indian Ocean $(P$. alphonsianus Hoffman, 1874 from Reunion Island; P. parvus Hoffman, 1874 from Nossy-Faly Island, Madagascar; and P. malliardi Richters, 1880 from Mauritius). 
This study aims to clarify the evolutionary independence of lineages within the complex " $M$. australe", using both molecular and morphological characters. A molecular phylogeny was performed based on the DNA sequencing of two unlinked molecular markers (16S and 28S rRNA) in 53 specimens sampled over an area that covers the range of " $M$. australe", and includes localities close to the type localities of the synonymous species. To construct a robust molecular taxonomic framework, all published sequences of Macrobrachium were included in the phylogenetic analyses. This allowed the assessment of the status of "M. australe" lineages relative to one another and relative to other species of the genus Macrobrachium. Next, in order to assign molecular clusters to correct species names, morphological characters within and among the divergent genetic clusters identified as " $M$. australe" were examined and compared to all museum data (from collections of voucher specimens and from original descriptions or taxonomic revisions) available on $M$. australe and its seven associated synonyms. Diagnostic morphological characters of identified species were compiled to facilitate future identifications within the "M. australe" complex.

\section{Material and methods}

\section{Collection, molecular data and analyses}

Specimens were collected in the Indo-West Pacific (Fig. 1, Table 1) by electrofishing (portable Dekka 3000 electric device, Germany). In the field, most of the specimens were released back into the river after a piece of pereiopod was clipped off and fixed in $95 \%$ ethanol for molecular analyses. Only some specimens (mostly corresponding to mature males presenting morphological features enabling specieslevel taxonomic identification) were kept intact and fixed in 75\% ethanol for morphological analyses.

A fragment of the mitochondrial 16S rRNA gene and a fragment of the nuclear 28S rRNA gene, including the D1 and D2 domains (Hassouna et al. 1984; Palumbi et al. 1991), were amplified using the universal primers 16Sa-L and 16Sb-H2 (Palumbi 1996) and C1 and D2 (Jovelin \& Justine 2001), respectively. Polymerase chain reaction (PCR) protocols were described in Castelin et al. (2013). PCR products were sequenced in both directions to insure the accuracy of base calls. Chromatograms were edited

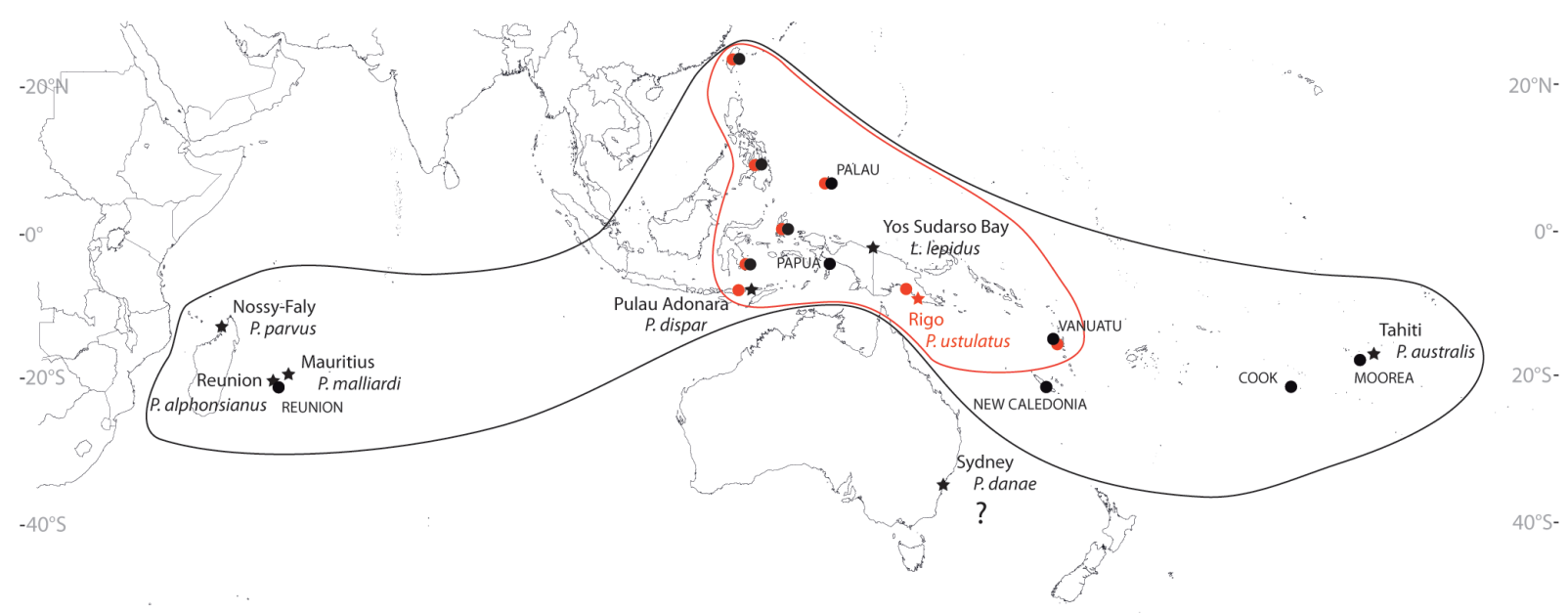

Fig. 1. Map of the Indo-Pacific showing localities where Macrobrachium australe (Guérin-Méneville, 1838 in Guérin-Méneville 1829-1838) (black area) and M. ustulatum (Nobili, 1899) (red area) were collected and/or recorded. Capitalized locality names correspond to the 7 localities sampled for this study. Non-capitalized locality names correspond to the localities reported from the literature. Stars shows the type localities of the synonyms of M. australe (black stars) and M. ustulatum (red star). 


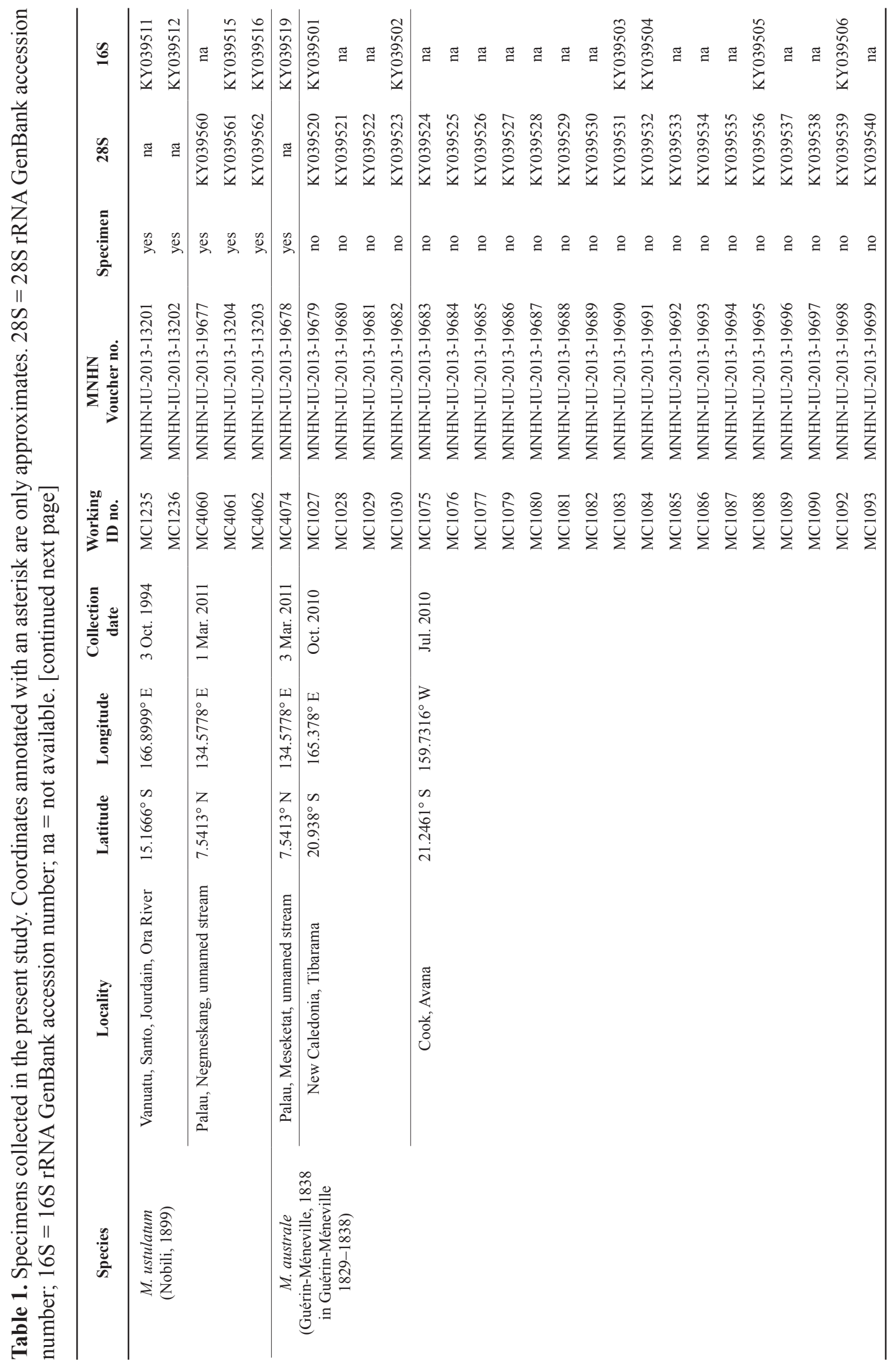




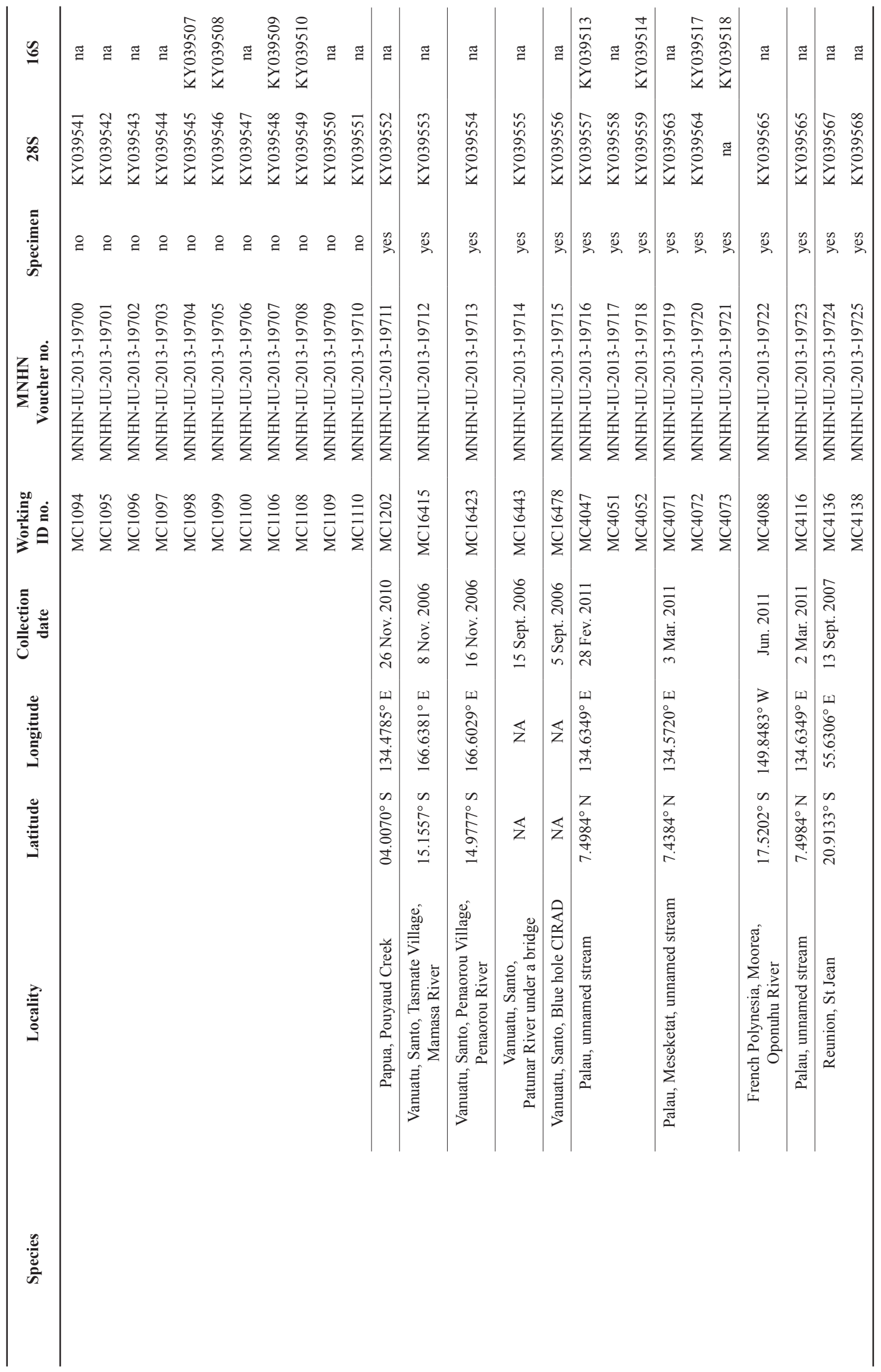


using CodonCode Aligner v. 4.1.1 (CodonCode Corporation, Dedham, MA, USA) and sequences were deposited in GenBank (accession numbers: KY039501-KY039568, Table 1).

Sequences were used to search the NCBI database for related sequences using the Sequence Search (MegaBlast algorithm) tool implemented in Geneious software (Biomatters Ltd) for highly similar sequences (Zhang et al. 2000). Related sequences (Appendix) were downloaded and aligned with our sequences using the MUSCLE Server (Edgar 2004). Sequences from P. debilis Dana, 1852 were used as outgroup. Poorly aligned sites in the $28 \mathrm{~S}$ dataset were identified using Gblocks Server v. 0.91b (Castresana 2000) and removed from analyses. Parameters used in Gblocks allowed for smaller final blocks and gap positions within the final blocks. Identical sequences were identified using DnaSP v. 5 (Librado \& Rozas 2009) and one representative sequence retained for each haplotype. Nucleotide substitution models were determined using BIC in jModelTest v. 2.1.6 (Darriba et al. 2012).

A phylogeny was inferred for each gene using the Bayesian inferences (BI) implemented in BEAST v. 1.8.2 (Drummond et al. 2012). BEAST input files were generated using BEAUti v. 1.8.0 (Drummond et al. 2012). The Yule model was used as a prior for the speciation process. When an optimal nucleotide substitution model was not available in BEAUti we selected a similar but more complex near-optimal model (Huelsenbeck \& Rannala 2004). The heterogeneity of the mutation rate across lineages was set under an uncorrelated, relaxed log-normal clock and mean rate was fixed to one. Each analysis ran for 100000000 generations with sample frequency of 1000 . The final trees were calculated based on 99000 trees (after burning 1001 generations) with maximum clade credibility and median node heights. Length of burning was determined by examination of traces in Tracer v. 1.6 (Rambaut et al. 2014). In addition, to better assess the robustness of nodes, a Maximum Likelihood (ML) tree using the GTR $+\Gamma$ model of rate substitution (the most inclusive model) was inferred for each gene using RAxML HPC2 (Stamatakis 2006) on Teragrid v. 7.2.7, implemented in the Cyber Infrastructure for Phylogenetic Research (CIPRES) portal v. 3.1 (Miller et al. 2011). The best-scoring ML tree was estimated from 100 independent searches, each starting from distinct random trees. Robustness of nodes was assessed using the rapid bootstrapping algorithm (1000 replicates) (Felsenstein 1985; Stamatakis et al. 2008).

After checking for congruency between $16 \mathrm{~S}$ and $28 \mathrm{~S}$ tree topologies, a concatenated dataset was built using BI and ML analyses similar to those described above. Sequence variation was partitioned between genes and gene-specific nucleotide substitution model parameters were used, with each gene allowed to evolve at a different rate. Nucleotide substitution models were similar to those used in the single-gene phylogenies.

\section{Morphological study}

Morphological observations were made on the specimens sampled in this study, as well as on specimens from various European museum collections corresponding to $M$. australe and its synonyms. The rostrum, the general cephalon, the second pereiopods and the abdomen were observed using a stereoscopic microscope. The carapace length and the proportions of the various joints of the second chelipeds were measured using callipers (under stereoscopic microscope when needed). Drawings were made using the "Digital Inking" method (Coleman 2003; Coleman 2006) by tracing vectorial paths on high resolution photographs with Adobe Illustrator (CS6) equipped with a WACOM PTZ-1230 graphic tablet.

Abbreviations:

$\mathrm{CAL}=$ carpus length

CED = cutting edge of dactylus

$\mathrm{CEFF}=$ cutting edge of fixed finger

$\mathrm{CHL}=$ chela length 


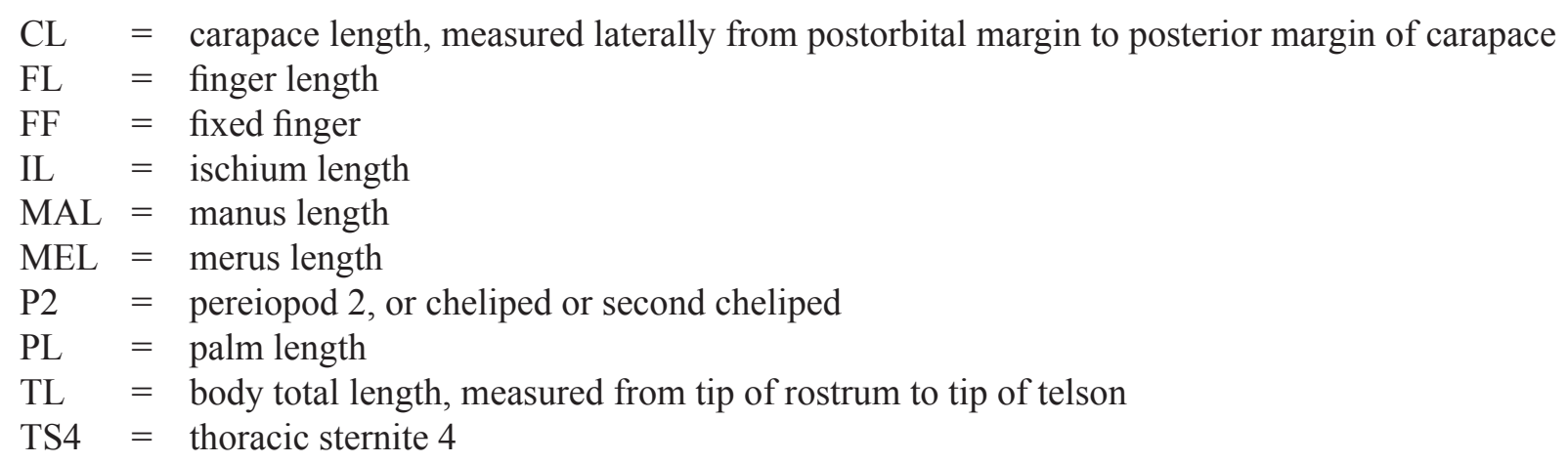

Museum abbreviations:

MNHN $=$ Muséum national d'Histoire naturelle, Paris, France

MSNG $=$ Museo Civico di Storia Naturale di Genova, Genoa, Italy

NHMW $=$ Naturhistorisches Musem Wien, Vienna, Austria

RMNH $=$ Naturalis Biodiversity Center, Leiden, the Netherlands

$\mathrm{ZMB}=$ Zoologisches Museum Berlin, Germany

\section{Results}

\section{Molecular analyses}

Fifty-three specimens were successfully sequenced for their $16 \mathrm{~S}$ or $28 \mathrm{~S}$ gene, or both (Table 1). The 19 amplified $16 \mathrm{~S}$ sequences included $520 \mathrm{bp}$ containing 36 variable sites. The 49 amplified $28 \mathrm{~S}$ sequences included $743 \mathrm{bp}$ containing 33 variable sites. After alignment with 53 sequences from Genbank (Appendix), the 16S dataset of $520 \mathrm{bp}$ of the ingroup included 299 variable sites, of which 167 were phylogenetically informative. The $28 \mathrm{~S}$ dataset of $774 \mathrm{bp}$ of the ingroup included 305 variable sites, of which 245 were phylogenetically informative. After alignment with 62 sequences from Genbank (Appendix) and removal of ambiguous blocks, $504 \mathrm{bp}$ of sequence remained to be used in phylogenetic analyses (65\% of the original 774 positions), of which $144 \mathrm{bp}$ were variable and 123 bp phylogenetically informative.

In each of the $16 \mathrm{~S}$ and $28 \mathrm{~S}$ trees, specimens originally assigned to " $M$. australe" were segregated into two groups (hereafter named group 1 and group 2, Fig. 2) that appeared as sister taxa, and were genetically distinct from one another and from all other species included in the tree. Indeed, group 1 and group 2 formed a monophyletic group, highly supported by posterior probabilities (PP) and bootstrap (B) analyses (16S: $\mathrm{PP}=1, \mathrm{~B}=96 ; 28 \mathrm{~S}$ : $\mathrm{PP}=1, \mathrm{~B}=95$ ) (Fig. 2), and the monophyly of each group was supported by both $\mathrm{PP}$ and $\mathrm{B}$ with both genes (16S: group 1: $\mathrm{PP}=1, \mathrm{~B}=98$; group 2 : $\mathrm{PP}=1, \mathrm{~B}=100$; $28 \mathrm{~S}$ : group 1: $\mathrm{PP}=1, \mathrm{~B}=85$; group 2: $\mathrm{PP}=1 ; \mathrm{B}=100$ ). Analysis based on the concatenation of $16 \mathrm{~S}$ and $28 \mathrm{~S}$ could only be performed on the M. australe complex and M. lar (Fabricius, 1798), for which the 2 genes were available. In this phylogeny, although the monophyly of the two groups was supported (group 1: $\mathrm{PP}=1, \mathrm{~B}=100$; group $2: \mathrm{PP}=1, \mathrm{~B}=100$ ), the relationship of the two groups as sister taxa was not highly supported $(\mathrm{PP}=0.56, \mathrm{~B}=100)$ (data not shown).

Based on the 16S dataset, pairwise genetic distances between group 1 and group 2 varied from 5.2 to $5.9 \%$. Pairwise genetic distances within group 1 varied from 0 to $1.4 \%$, while no genetic variation was observed within group 2. Pairwise genetic distances between group 1 and palaemonid sequences ranged from 3.7 to $9.2 \%$, while genetic distances between group 2 and other palaemonid sequences ranged from 5.9 to $8.5 \%$. Based on the $28 \mathrm{~S}$ dataset, pairwise genetic distances between group 1 and group 2 varied from 2.2 to $2.4 \%$ (variation of 13 nucleotide sites out of $504 \mathrm{bp}$ ). Pairwise genetic distances within 
group 1 varied from 0 to $0.6 \%$, while no genetic variation was observed within group 2. Pairwise genetic distances between group 1 and sequences of Macrobrachium ranged from 2.2 to $12.2 \%$, while genetic distances between group 2 and other sequences of Macrobrachium ranged from 2.2 to $11.9 \%$.

\section{Specimens morphologically examined from museum collections or from the literature}

For Palaemon danae from the NHMW, we used data from De Man (1892), and the comments of Holthuis (1950) and Short (2004). For P. dispar_ENREF_42from the RMNH, we used data from De Man $(1887,1892)$ and Roux (1933). For P. malliardi from the ZMB, we used the original description by Richters (1880) and the comments of Holthuis (1950). For Leander lepidus from the RMNH, we used the comments of Holthuis (1950). The type specimens of P. australis, deposited in an unknown collection, P. alphonsianus and P. parvus (both originally deposited at the RMNH) could not be examined, as the specimens are lost. For P. ustulatus from the MSNG, two syntypes from Rigo (Papua New Guinea) were examined. These corresponded to a male (specimen VII-106) and a female (specimen VII-105). In
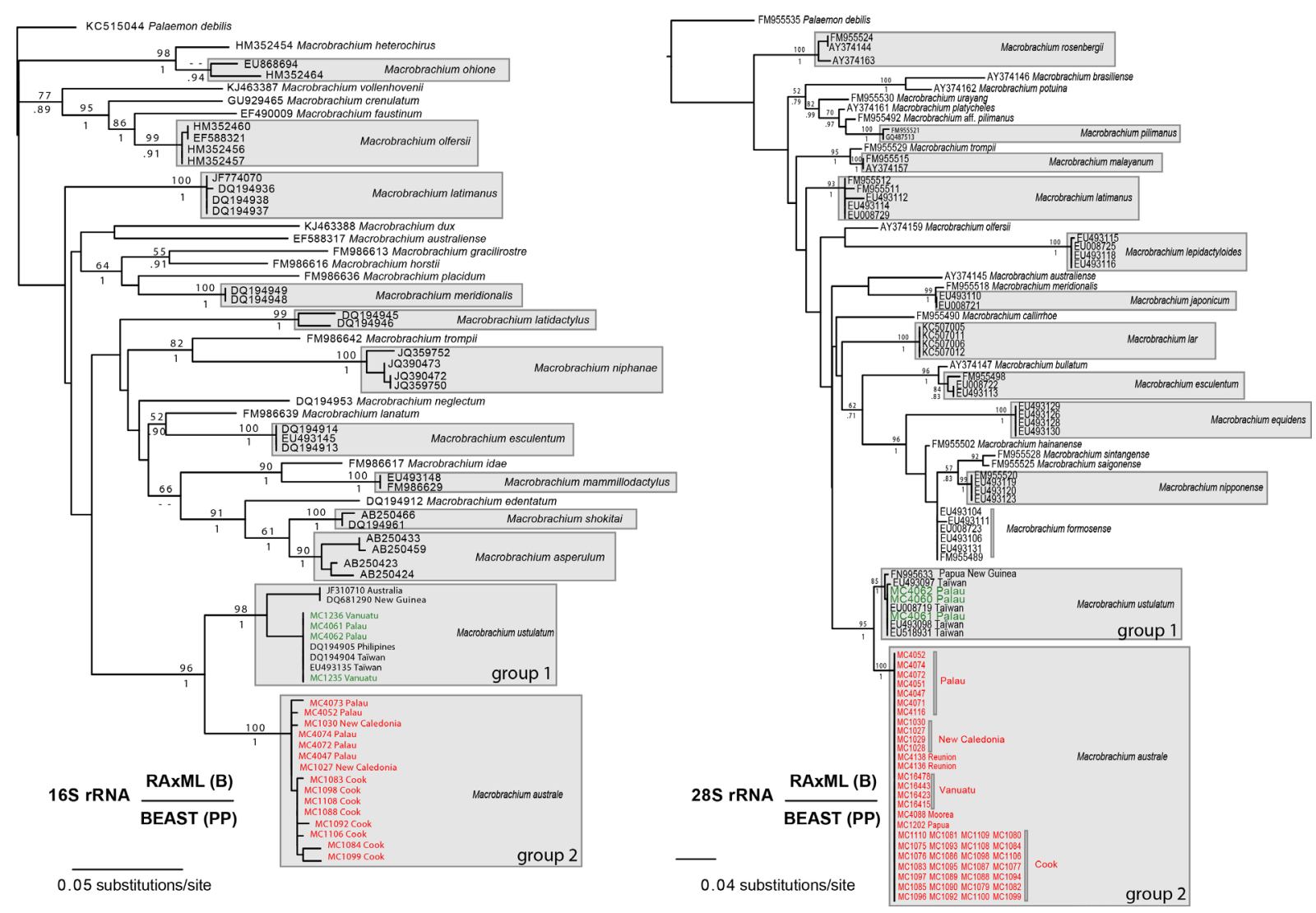

Fig. 2. Single-gene molecular phylogenies for Macrobrachium Spence Bate, 1868 based on the mitochondrial 16S and the nuclear 28S genes with Palaemon debilis Dana, 1852 as outgroup. Maximum likelihood (ML) and Bayesian (B) analyses, produced with BEAST and RAxML, respectively. Support values from Maximum likelihood and Bayesian analyses are posterior probabilities (PP) and bootstraps (B), respectively. GenBank accession numbers and working ID numbers are given at nodes. Species names are given on the right-hand side. The name of the sequences produced in the present study are colored in red for M. australe (Guérin-Méneville, 1838 in Guérin-Méneville 1829-1838) and in green for $M$. ustulatum (Nobili, 1899). For these, sampling locality are given at nodes. See Table 1 and Appendix for details. 
addition, five specimens from the MNHN, recorded under the name of $M$. australe, were examined: two specimens (MNHN-IU-2013-13201 and MNHN-IU-2013-13202) were collected in the Ora River on Santo Island (Vanuatu), one specimen (MNHN-IU-2013-13199) was collected from Anjouan (Comoros Islands), three specimens (MNHN-IU-2013-13196, MNHN-IU-2013-13197, MNHN-IU-2013-13198) were collected on Rarotonga (Cook Islands), and one specimen (MNHN-IU-2013-13200) on Pentecost Island (Vanuatu).

\title{
Morphological study
}

In order to assign molecular clusters to correct species name, morphological characters within and among the genetic clusters, identified in phylogenetic analyses as "M. australe", were examined and compared to all available museum data on " $M$. australe" and its eight associated synonyms (i.e., collections of voucher specimens and descriptions or taxonomic revisions). Specimens of group 1 were assigned to Macrobrachium ustulatum (Nobili, 1899) and specimens of group 2 to M. australe (Table 2). The holotype of Palaemon ustulatus from MSNG is represented by one male only with the minor second cheliped (Table 2). The proportions of the various joints of the cheliped do not match with the morphology of the specimens belonging to $M$. australe: $\mathrm{CAL} / \mathrm{CHL}=0.69$ (vs 0.79-1.04); $\mathrm{CAL} / \mathrm{PL}=1.15$ (vs 1.191.60 ) and $\mathrm{FL} / \mathrm{PL}=0.66$ (vs $0.46-0.53$ ) (Table 2). Moreover, these characteristics fit well with those observed on specimens identified as $M$. ustulatum: $\mathrm{CAL} / \mathrm{CHL}=0.67-0.75 ; \mathrm{CAL} / \mathrm{PL}=1.01-1.25$ and $\mathrm{FL} / \mathrm{PL}=0.49 / 0.66$ (Table 2). The holotype shows an epistome with lobes strongly produced anteroventrally (vs not strongly diverging anteriorly) and a fourth thoracic sternite armed with a rounded median process (vs unarmed). Overall, six characters were identified as diagnostic to distinguish the two species (Table 3).

Out of the seven synonyms of $M$. australe, six were confidently identified as junior synonyms based on the rostrum shape, the position of the hepatic spine toward the antennal spine and the proportions of the male second pereiopod (Table 4). The seventh synonym, P. ustulatus is no longer considered as such.

\section{Systematic Account}

\author{
Infraorder Caridea Dana, 1852 \\ Superfamily Palaemonoidea Rafinesque, 1815 \\ Family Palaemonidae Rafinesque, 1815 \\ Subfamily Palaemoninae Rafinesque, 1815
}

Macrobrachium Bate, 1868

Macrobrachium australe (Guérin-Méneville, 1838 in Guérin-Méneville 1829-1838)

Fig. 3, Table 2

Palaemon australis Guérin-Méneville, 1838 in Guérin-Méneville 1829-1838: 37 ("Île de Taïti”= Tahiti). Palaemon danae Heller, 1865: 120, pl. 11, fig. 4 ("Sydney"; synonymy considered erroneous by Short 2004).

Palaemon dispar von Martens, 1868: 41 ("Insel Adenare, unweit Flores" = Adenare Island, near Flores). Palaemon alphonsianus Hoffmann, 1874: 33, pl. 9, figs 63-65 ("l'île de la Réunion" = Reunion Island). Palaemon parvus Hoffmann, 1874: 35, pl. 7, fig. 59 ("l'île de Nossy-Faly" = Nosy Faly Island).

Palaemon malliardi Richters, 1880: 166, pl. 18, figs 1-3 ("Creole River, Black River, Mauritius Is."). Leander lepidus de Man, 1915: 410, pl. 28, figs 6-6d ("Mündung des kleinen Flusses zu Oinaké, einem Dorfe an der Küste östlich von der Humboldt-Bai" = mouth of a small river at Oinaké, a coastal village east of Humboldt Bay (Yos Sudarso Bay), Papua). 


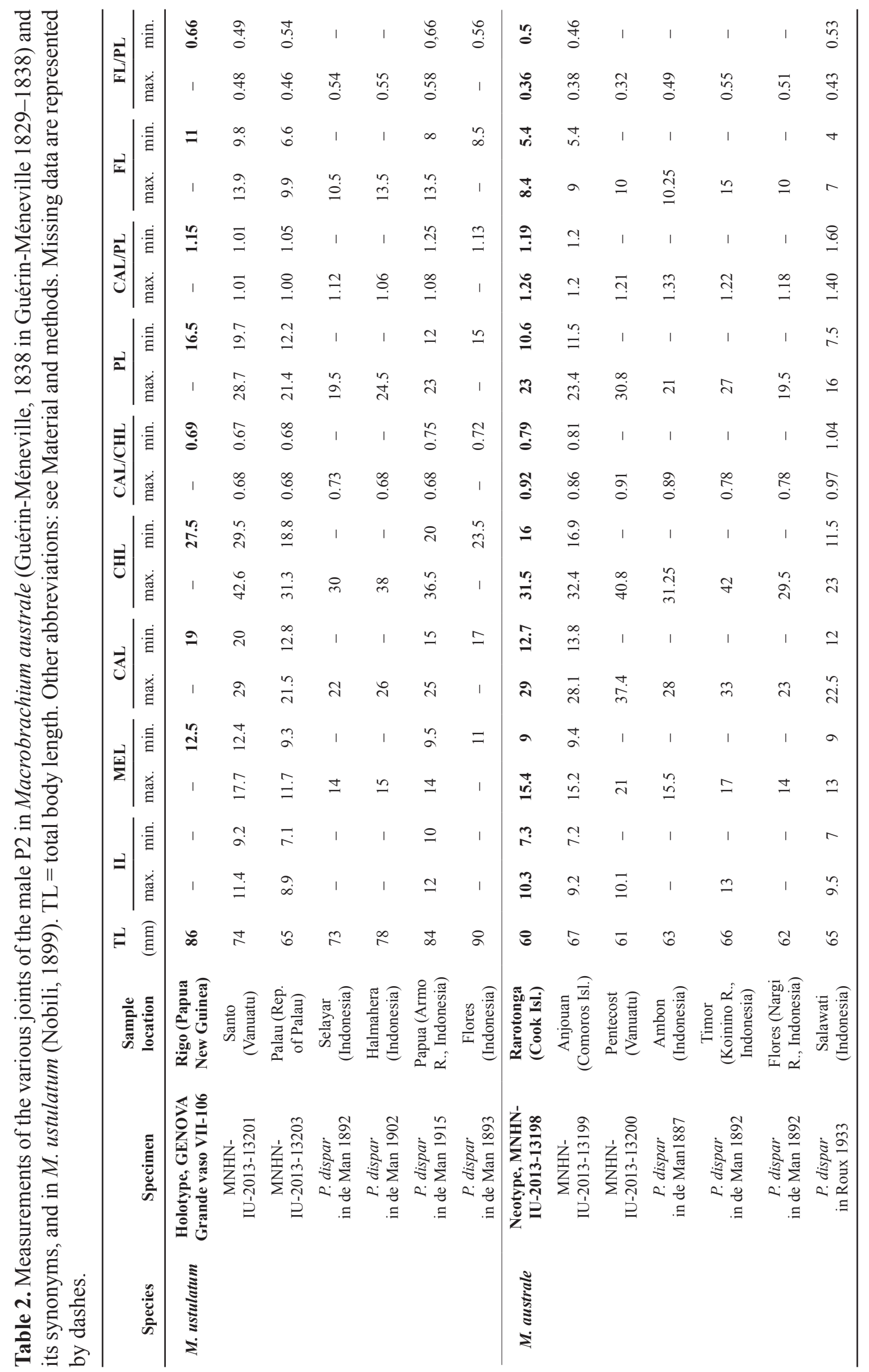


Table 3. Traits of six characters identified as diagnostic to distinguish Macrobrachium australe (GuérinMéneville, 1838 in Guérin-Méneville 1829-1838) from M. ustulatum (Nobili, 1899).

\begin{tabular}{|c|c|c|c|}
\hline & Diagnostic characters & Macrobrachium australe & Macrobrachium ustulatum \\
\hline 1 & $\begin{array}{l}\text { Proportion between major and } \\
\text { minor pereiopod lengths }\end{array}$ & $1.48-2$ & $1.37-1.59$ \\
\hline 2 & $\begin{array}{l}\text { Proportions of the joints of the } \\
\text { major male P2 }\end{array}$ & $\begin{array}{c}\text { CAL/CHL } 0.78-0.97 \\
\text { CAL/PL 1.18-1.40 } \\
\text { FL/PL 0.32-0.55 }\end{array}$ & $\begin{array}{c}\text { CAL/CHL 0.68-0.73 } \\
\text { CAL/PL 1.00-1.12 } \\
\text { FL/PL 0.46-0.58 }\end{array}$ \\
\hline 3 & $\begin{array}{l}\text { Proportions of the joints of the } \\
\text { minor male P2 }\end{array}$ & $\begin{array}{c}\text { CAL/CHL } 0.79-1.04 \\
\text { CAL/PL 1.19-1.60 } \\
\text { FL/PL 0.46-0.53 }\end{array}$ & $\begin{array}{c}\text { CAL/CHL } 0.67-0.75 \\
\text { CAL/PL 1.01-1.25 } \\
\text { FL/PL } 0.49-0.66\end{array}$ \\
\hline 4 & $\begin{array}{l}\text { Velvety pappose setal pubescence } \\
\text { of the minor male P2 }\end{array}$ & $\begin{array}{l}\text { palm and bases of fingers only } \\
\text { densely packed with velvety setae }\end{array}$ & $\begin{array}{l}\text { palm and carpus densely } \\
\text { packed with velvety setae }\end{array}$ \\
\hline 5 & Epistome lobes & not strongly produced anteriorly & $\begin{array}{l}\text { strongly produced } \\
\text { antero-ventrally }\end{array}$ \\
\hline 6 & Fourth thoracic sternite & unarmed & $\begin{array}{l}\text { armed with a round } \\
\text { median process }\end{array}$ \\
\hline
\end{tabular}

\section{Material examined}

Neotype

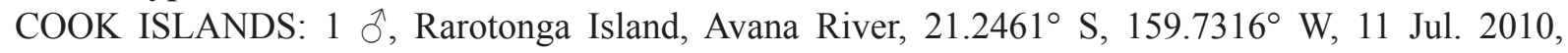
15.3 mm CL (MNHN-IU-2013-13198).

\section{Other material}

COOK ISLANDS: $1 \curvearrowright$, same collection data, 12 mm CL (MNHN-IU-2013-13196); $1 \curvearrowright$, 14.5 mm CL (MNHN-IU-2013-13197).

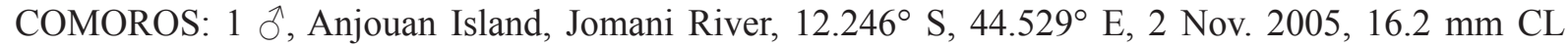
(MNHN-IU-2013-13199).

VANUATU: $1{ }^{\lambda}$, Pentecost Island, Warbot River, $15.957^{\circ} \mathrm{S}, 168.195^{\circ} \mathrm{E}, 26 \mathrm{Jan} .2010,14.3 \mathrm{~mm}$ CL (MNHN-IU-2013-13200).

\section{Description}

Rostrum. Moderately long, reaching to or slightly beyond end of scaphocerite (Fig. 3A); tip slightly upcurved; dorsal margin with 10-11 teeth, including 2-3 teeth on carapace; ventral margin with 3-4 teeth; teeth large, evenly spaced; sometimes distance between ultimate and penultimate teeth much larger than distances between other teeth; sometimes distance between $1^{\text {st }}$ and $2^{\text {nd }}$ teeth larger than between $2^{\text {nd }}$ and $3^{\text {rd }}$ teeth.

General CEPHALOn. Eyes well developed; cornea as long as, but broader than peduncle; stylocerite distinctly pointed, reaching beyond basal segment; inferior orbit bluntly angular (Fig. 3A); postantennular carapace margin straight or slightly concave; protective setation absent on carapace; epistome lobes narrowly separated, not strongly diverging anteriorly (Fig. 3B); TS4 unarmed (Fig. 3C).

SeCOND CheLIPEDs (fully developed $\precsim$ ). Very unequal sizes, non-isomorphic. Major P2 (Fig. 3D) long, subcylindrical, merus extending beyond scaphocerite; carpus 0.78-0.97 CHL, 1.18-1.40 PL. Fingers slender, 0.32-0.55 PL; dactylus shorter than FF. Cutting edges (Fig. 3E) with 4-5 conical teeth at base 


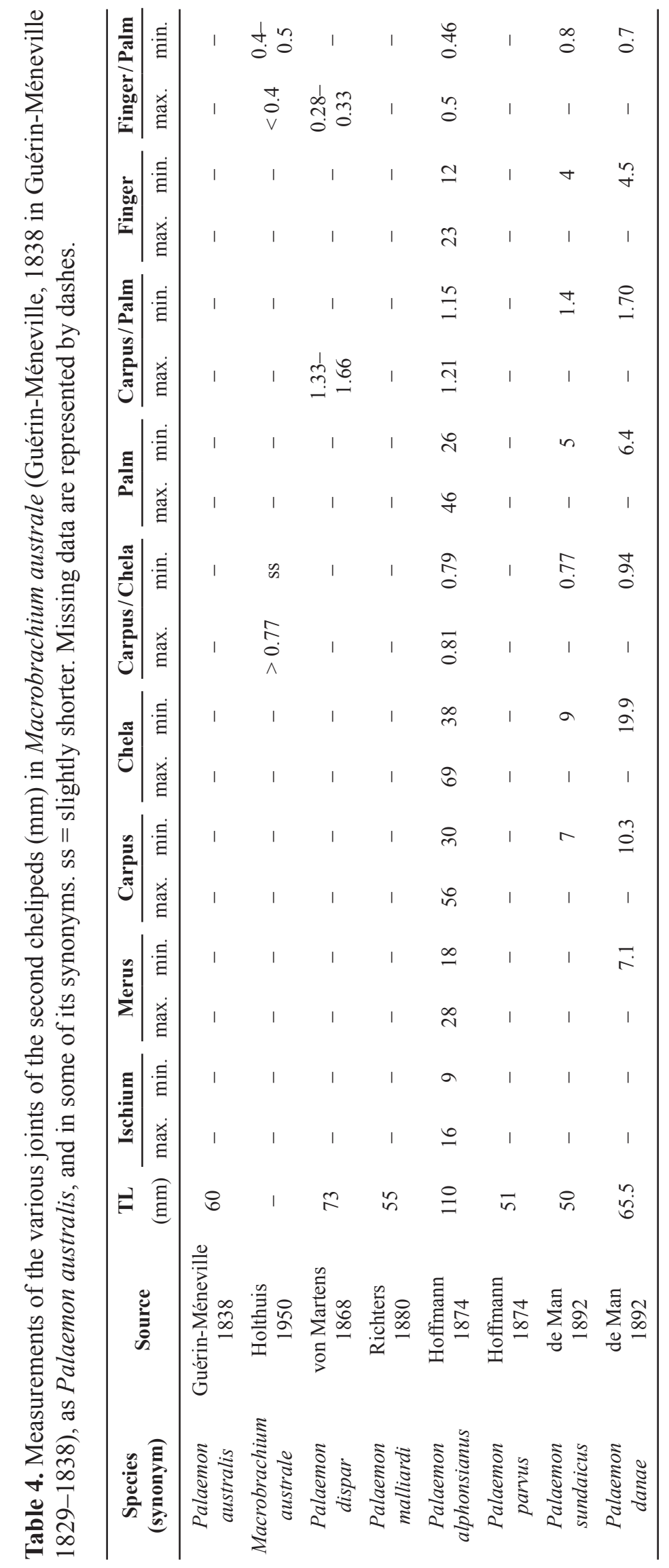




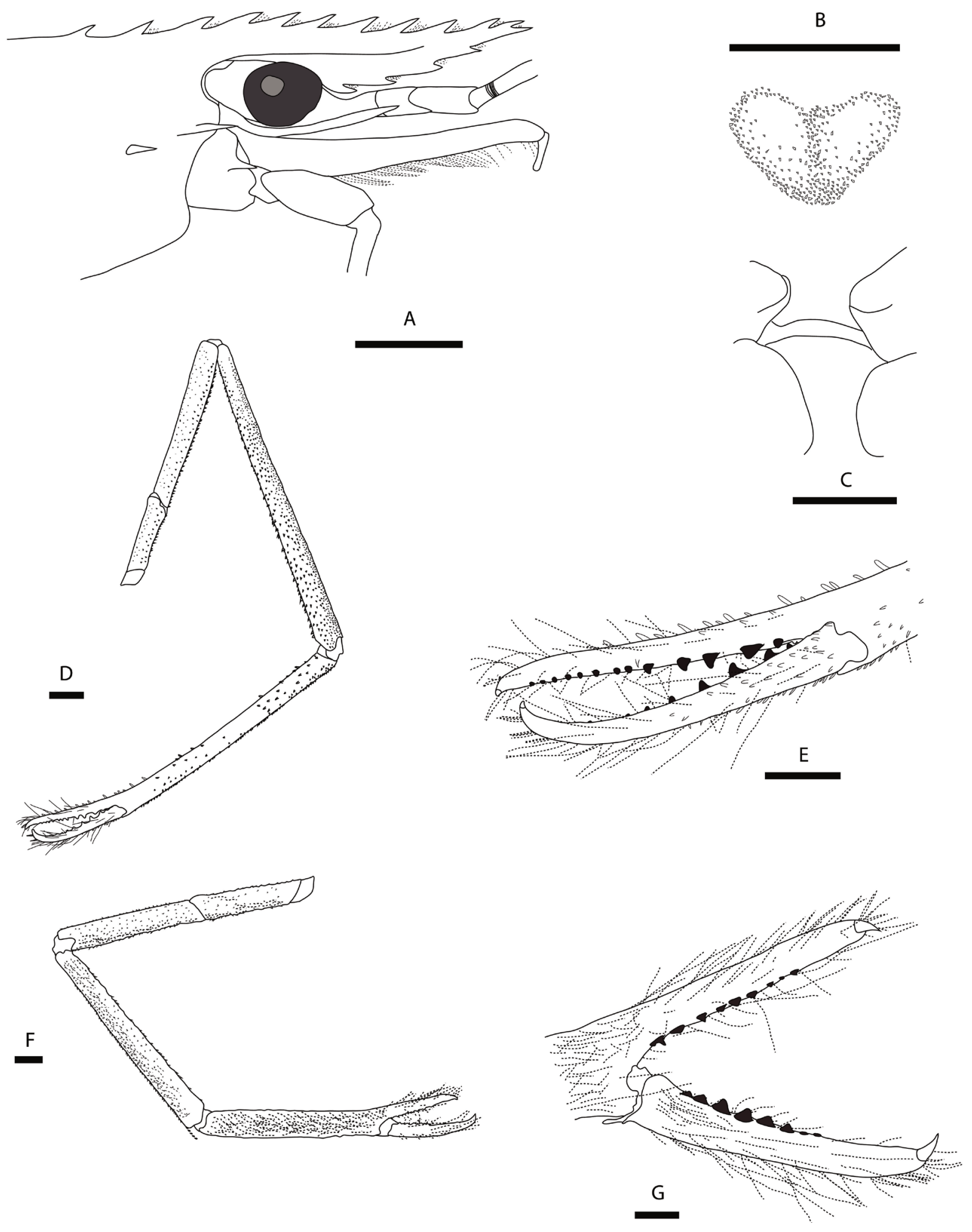

Fig. 3. Macrobrachium australe (Guérin-Méneville, 1838 in Guérin-Méneville 1829-1838), MNHNIU-2013-13198. A. Cephalothorax. B. Epistome. C. Fourth thoracic sternite. D. Major second pereiopod. E. Major second pereiopod finger. F. Minor second pereiopod. G. Minor second pereiopod finger. Scale bars: A, E, G = $2 \mathrm{~mm}$; $\mathrm{B}-\mathrm{C}=1 \mathrm{~mm} ; \mathrm{D}, \mathrm{F}=4 \mathrm{~mm}$. 
( ${ }^{\text {rd }}$ largest) followed by 9-14 evenly spaced, small, blunt teeth along entire length; teeth diminishing in size distally; FF elongated, curved inwards; teeth arrangement similar to that of dactylus; basal part armed with 5-6 conical teeth ( $3^{\text {rd }}$ largest) followed by 9-16 evenly spaced, small, blunt teeth along entire length; teeth diminishing in size distally. Largest tooth of FF lies after largest tooth of dactylus. Cheliped with numerous large spiniform setae on inner edge, smaller and denser on outer edge. Some scattered long setae present on cheliped, but very distinct on fingers. Merus 0.51-0.60 CAL, ischium 0.48-0.76 MEL. Minor P2 (Fig. 3F) with entire carpus beyond scaphocerite. Carpus 0.79-1.04 CHL, 1.19-1.60 PL. Fingers slender, 0.46-0.53 PL. Palm and bases of fingers densely packed with velvety setae. CED (Fig. 3G) with 6-13 teeth along entire length diminishing in size. CEFF with 9-15 teeth, similar teeth arrangement to that of dactylus, but teeth smaller. Pereiopods with numerous spiniform setae, denser on lower edge. MEL 0.60-0.81 CAL, IL 0.76-0.81 MEL.

AвDOMEn. Smooth, inter-uropodal sclerite with preanal carina.

\section{Remarks}

Since the type specimen of $P$. australis is lost, and because of the taxonomic problems discussed above, a specimen from the Avana River on Rarotonga Island (Cook Islands, Central Pacific), which is geographically close to the type locality of $P$. australis (Tahiti), is herein designated as the neotype of $M$. australe in order to stabilize the taxonomy of the species. One specimen in our sample was collected from Moorea, which is closer to Tahiti. However, the specimen was in a less good condition than specimens from Rarotonga; thus, diagnostic morphological characters defined in this study were less obvious. Specimens from Rarotonga and from Moorea, however, showed no genetic variation in both the $28 \mathrm{~S}$ and the $16 \mathrm{~S}$ genes.

\section{Distribution}

From the Indian Ocean (Madagascar, Comoros and Mascarenes Islands) to the Central Pacific Ocean (French Polynesia and Cook Islands). Syntopic with M. ustulatum in the Northwest Pacific Ocean (Taiwan, Philippines, Indonesia, Papua New Guinea and Palau) and the Southwest Pacific Ocean (Vanuatu) (Fig. 1).

\section{Habitat}

Lentic habitats in the lower courses of rivers and at the edge of rivers, in water plant communities (Keith et al. 2013).

\section{Color patterns}

Body colors (Fig. 4A) tend to match the substrate, varying from grey to brown, rather translucent, with three reddish stripes on each side of the cephalothorax.

Macrobrachium ustulatum (Nobili, 1899)

Fig. 5, Table 2

P.[alcemon] (Eupalcemon) ustulatus Nobili, 1899: 241 (Rigo, SE Papua).

Palaemon ustulatus - de Man 1915: 431, pl. 29, fig. 32 (Rigo, SE Papua).

\section{Material examined}

Holotype

PAPUA NEW GUINEA: $1{ }^{\lambda}$, Rigo District, $9.8767^{\circ} \mathrm{S}, 147.7938^{\circ} \mathrm{E}$, unknown date, $23.5 \mathrm{~mm} \mathrm{CL}$ (MSNG VII-106). 

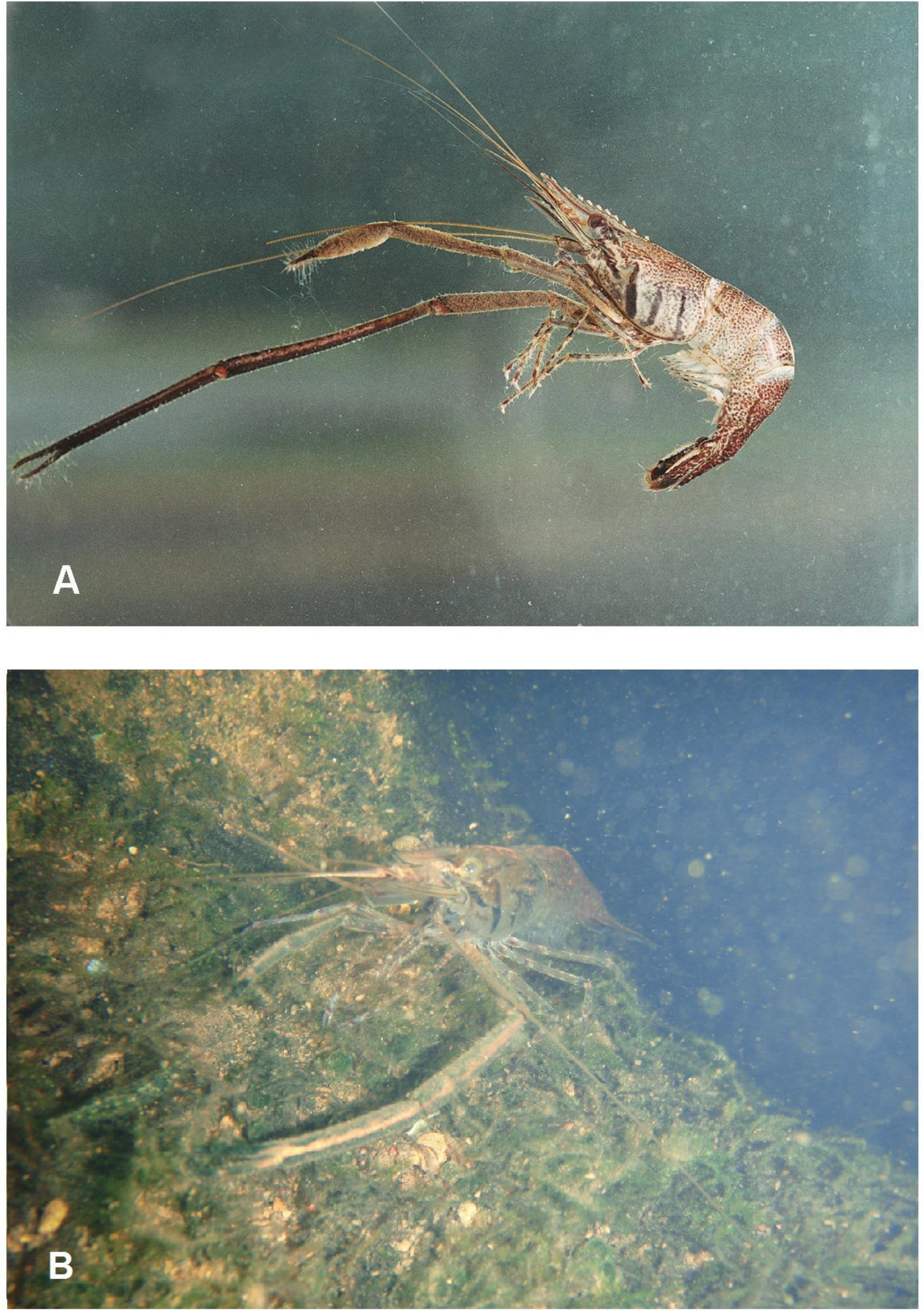

Fig. 4. A. Live coloration of Macrobrachium australe (Guérin-Méneville, 1838 in Guérin-Méneville 1829-1838) (photo: E. Vigneux). B. Live coloration of M. ustulatum (Nobili, 1899) (photo: P. Keith). 


\section{Other material}

VANUATU: 1 đ̊, Espiritu Santo Island, Ora Jourdain River, $15.1666^{\circ} \mathrm{S}, 166.8999^{\circ}$ E, 3 Oct. 1994, 20.7 mm CL (MNHN-IU-2013-13201); 1 ô, 22 mm CL (MNHN-IU-2013-13202).

REPUBLIC OF PALAU: 1 ภ, Palau Island, Negmeskang River, $7.5413^{\circ} \mathrm{N}, 134.5778^{\circ} \mathrm{E}, 1$ Mar. 2011, 20.7 mm CL (MNHN-IU-2013-13203).

\section{Description}

RosTRUM. Moderately long, reaching end of scaphocerite (Fig. 5A); tip horizontal; dorsal margin nearly straight, faintly convex, with 10-12 teeth, including 3 teeth on carapace; ventral margin with 3-4 teeth; teeth large, generally evenly spaced, with gap near anterior end of dorsal series; sometimes distance between $1^{\text {st }}$ and $2^{\text {nd }}$ teeth larger than between $2^{\text {nd }}$ and $3^{\text {rd }}$ teeth.

General CEPHalon. Eyes well developed; cornea as long as, but broader than peduncle; stylocerite distinctly pointed, reaching beyond basal segment; inferior orbit bluntly angular (Fig. 5A); postantennular carapace margin straight or slightly concave; protective setation absent on carapace; epistome lobes narrowly separated, strongly produced anteroventrally (Fig. 5B); TS4 with rounded median process (Fig. 5C).

SeCond CHeLIPeds (fully developed $\precsim$ ). Unequal sizes, non-isomorphic. Major P2 (Fig. 5D) long, subcylindrical, with small part of merus extending beyond scaphocerite; carpus 0.68-0.73 CHL, 1-1.12 PL. Fingers slender 0.46-0.58 PL; dactylus shorter than FF. Cutting edges (Fig. 5E) with 4-5 conical teeth $\left(3^{\text {rd }}\right.$ largest) followed by 6-10 evenly spaced, very small, blunt teeth, not along entire length; teeth diminishing in size distally; CEFF with teeth arrangement similar to that of dactylus; basally armed with ridge formed by 2 small teeth and 3-4 larger, conical teeth followed by 4-6 evenly spaced, small, blunt teeth, not along entire length; teeth diminishing in size distally. Largest tooth of FF lies just after largest tooth of CED when fingers closed. Cheliped with numerous spiniform setae, larger on inner edge, smaller and denser on outer edge. Numerous long setae present on manus and outer edge of fingers. Merus 0.54-0.61 CAL, ischium 0.64-0.85 MEL. Minor P2 (Fig. 5F) with entire carpus beyond scaphocerite. Carpus 0.67-0.75 CHL, 1.01-1.25 PL. Fingers slender 0.49-0.66 PL. CEFF with 11-14 teeth, gradually diminishing in size distally (Fig. 5G). CED with 13-15 teeth, slightly smaller and more numerous than those of major P2, similar teeth arrangement to that of dactylus. Fingers, palm and carpus densely packed with velvety setae. MEL 0.62-0.72 CAL, IL 0.74-1.05 MEL.

AвDомEn. Smooth, inter-uropodal sclerite with preanal carina.

\section{Distribution}

Syntopic with M. australe in the Northwest Pacific Ocean (Taiwan, Philippines, Papua New Guinea, Indonesia and Palau) and in the Southwest Pacific Ocean (Vanuatu) (Fig. 1).

\section{Habitat}

Lotic habitats in the middle course of rivers, clear and oxygenated waters, sometimes above waterfalls. Rocky substrates, boulders, pebbles and pools in countercurrents.

\section{Color patterns}

Body colors (Fig. 4B) tend to match the substrate, varying from black to brownish red, with three reddish stripes on each side of the cephalothorax.

\section{Remarks}

Some specimens originally assigned to $P$. dispar may correspond to M. ustulatum. This applies to de Man 1892: 435, pl. 26, fig. 44d (Salayar Island, Indonesia); de Man 1893: 304 (Flores, Indonesia); 


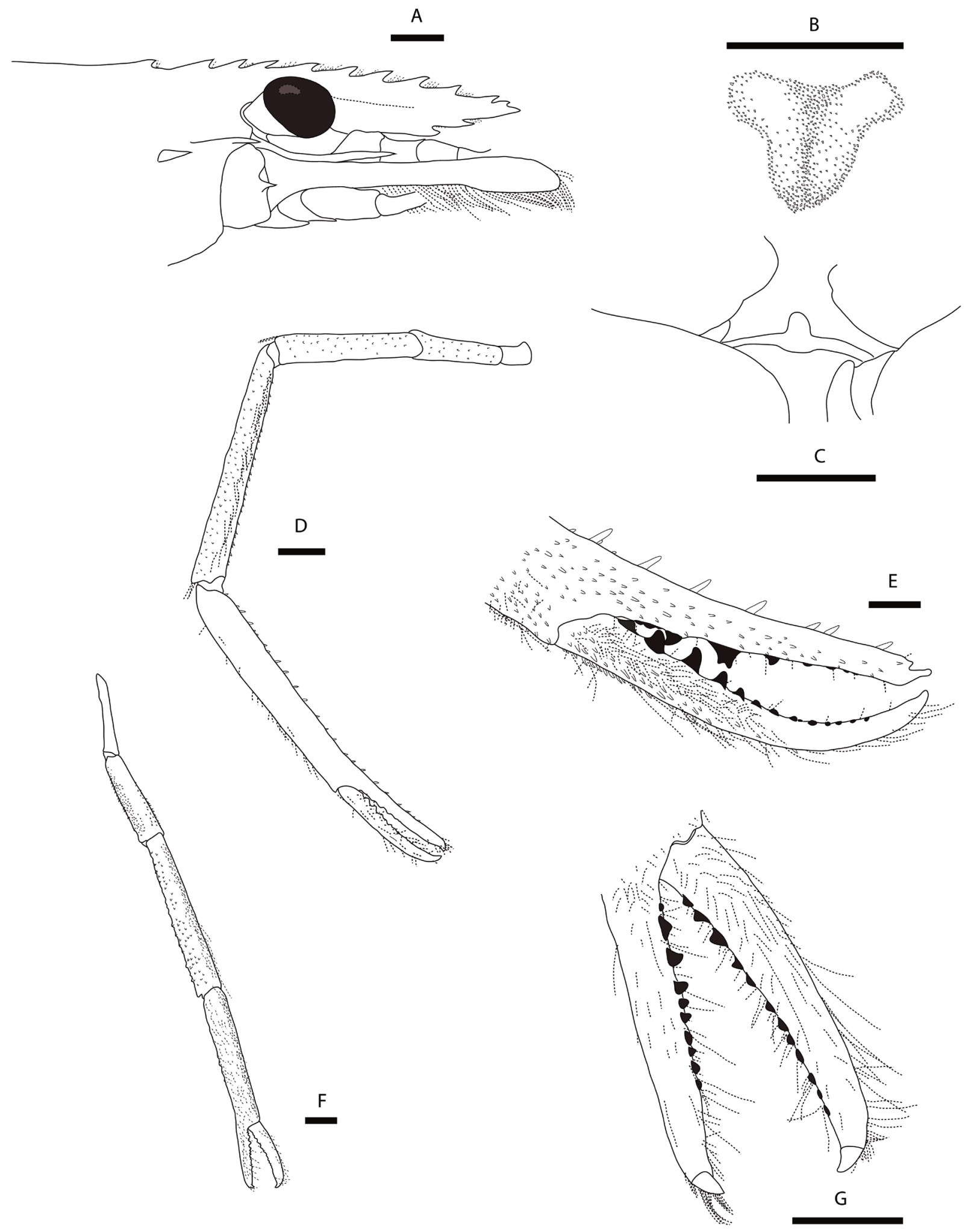

Fig. 5. Macrobrachium ustulatus (Nobili, 1899). - A-B, E. MNHN-IU-2013-13202. A. Cephalothorax. B. Epistome. E. Major second pereiopod finger. - C, G. MNHN-IU-2013-13201. C. Fourth thoracic sternite. G. Minor second pereiopod finger. - D, F. MNHN-IU-2013-13203. D. Major second pereiopod. F. Minor second pereiopod. Scale bars: A, E, G $=2 \mathrm{~mm}$; B-C $=1 \mathrm{~mm} ; \mathrm{D}, \mathrm{F}=4 \mathrm{~mm}$. 
de Man 1902: 766 (Halmahera, Indonesia); and de Man 1915: 435, pl. 29, figs 14-14a (Papua New Guinea).

\section{Discussion}

The DNA sequencing of two unlinked molecular markers in specimens collected from a large geographic range throughout the Indo-Pacific, covering the entire known distribution range of $M$. australe and including localities close to most of the type localities of its synonyms, suggested the existence of at least two distinct species under what is commonly assigned to " $M$. australe": M. australe (GuérinMéneville, 1838 in Guérin-Méneville 1829-1838), with a large distribution range from the Southwest Indian Ocean to the Central Pacific Ocean, and a cryptic species found syntopically at some islands of the Western Pacific Ocean (Taiwan, Philippines, Indonesia, Papua New Guinea, Palau and Vanuatu). Although they are not quite found in the same habitat (i.e., lentic vs lotic), the presence of these distinct genetic entities in the same rivers in Palau and the Santo Islands strongly favors the hypothesis that these genetic entities are reproductively isolated from one another. In addition, the two single-gene phylogenetic reconstructions, which included several species of Macrobrachium available from GenBank, suggested that the two species are closely related and could even be sister species. However, this hypothesis remains to be tested using a more comprehensive molecular dataset.

One of the main difficulties encountered in this study was to assign the genetic groups to the correct scientific name. Indeed, probably because of its large geographic range and morphological plasticity (Zimmermann et al. 2012), M. australe is currently also known under seven associated synonyms. Moreover, the lack of consensus on the diagnostic characters to use in the discrimination of species within this genus has led to descriptions that are difficult to compare. For instance, $P$. australis was described based on the shape of the rostrum; $P$. danae on the proportions of the various joints of the minor second pereiopod (see De Man 1892); P. dispar on the proportions of the major second pereiopod; P. alphonsianus on the second pereiopods; $P$. parvus on the rostrum, the position of the hepatic spine and the proportions of the minor second pereiopod; P. malliardi on the rostrum and the minor second pereiopod; P. ustulatus on the minor second cheliped; and L. lepidus on the rostrum, the cephalic region and the pereiopods I, II, III and IV (in very young specimens as well). In this context, to assign a scientific name to the cryptic species, we first sequenced specimens collected from or close to the type localities of all these synonymous species. For example, we studied samples from Moorea (French Polynesia) and Rarotonga (Cook Islands), which are close to the type locality of $P$. australe, Palau and Papua (close to the type localities of $P$. dispar, P. ustulatus and L. lepidus) and the Mascarene Islands (close to the type localities of $P$. alphonsianus, P. parvus and P. malliardi). We then examined the morphological characters of sequenced specimens, with particular attention toward mature male specimens, and compared these characters to museum samples and/or taxonomic descriptions of available synonyms.

Overall, molecular and morphological results both suggested that among the eight synonyms of $M$. australe, one (M. ustulatum) corresponds to a valid species, which therefore needs to be resurrected, one ( $P$. australis) corresponds to the original species name, and six are junior synonyms of M. australe ( $P$. danae, P. dispar, P. alphonsianus, P. parvus, P. malliardi, and L. lepidus). Indeed, based on rostrum shape, the position of the hepatic spine toward the antennal spine and the proportions of the male second pereiopod, P. danae, P. dispar, P. alphonsianus, P. parvus, P. malliardi and L. lepidus can be considered as junior synonyms of M. australe (Holthuis 1950; Chace \& Bruce 1993; de Grave \& Fransen 2011). On the contrary, the proportions of the various joints of the minor second cheliped (i.e., carpus/chela, carpus/palm and finger/palm) of the holotype of P. ustulatus from MCSN do not match with the morphology of specimens belonging to M. australe, but fit well with those corresponding to the cryptic species identified in this study, M. ustulatum. We also emphasized our morphological analyses on the epistome and fourth thoracic sternite, two features known to be very consistent between sexes and among individuals at different development stages (Short 2004). 
M. ustulatum lives in lotic habitats in the middle course of rivers. Indeed, P. dispar of de Man (1902) (most likely M. ustulatum) was from Halmahera, at an altitude of $600 \mathrm{~m}$.

Macrobrachium ustulatum was reported as P. dispar by de Man in 1892, 1893, 1902 and 1915. In 1915 de Man examined M. ustulatum from Papua New Guinea and gave a good illustration of its rostrum (de Man 1915: pl. 29, fig. 12). However he continued to report specimens from Papua New Guinea as P. dispar although they had the typical chelipeds of M. ustulatum (de Man 1915: pl. 29, figs 14, 14a). Later, $P$. dispar was always cited as one among several synonyms of $M$. australe, notably by Holthuis (1950), Chace \& Bruce (1993) and de Grave \& Fransen (2011). In addition, M. ustulatum has until now been confused with M. australe because of the similar shape of their rostrum, the numerous teeth on the cutting edges of the fingers of the male second pereiopods and the similar life color pattern.

\section{Conclusion}

Overall, genetic and morphological results show that M. australe and M. ustulatum belong to two distinct species. Macrobrachium australe (Guérin-Méneville, 1838 in Guérin-Méneville 1829-1838) has a widespread distribution, from Mascarene to French Polynesia, whereas M. ustulatum (Nobili, 1899) could be more restricted, from Taiwan to Vanuatu. Further studies should be conducted on the known geographic range of M. ustulatum, in order to assess more precisely its distribution. While the biology and ecology of M. australe is relatively well known (e.g., r-reproductive strategy; Ito et al. 2002; Wowor et al. 2009), the life history traits of $M$. ustulalum are totally unknown, and it is not unlikely that the life history traits of these two species have been mixed in previous studies. This raises questions about the exact distribution of M. ustulatum and its actual species conservation status. Unlike M. lar, the most widespread amphidromous prawn, which so far has revealed no cryptic species (Castelin et al. 2013), M. australe with a similar widespread distribution shows one. Chace \& Bruce (1993) and Wowor et al. (2009) all voiced their suspicions about the potential existence of many undescribed cryptic species in Macrobrachium. Furthermore, Liu et al. (2007) highlighted five cryptic species among the widespread East Asian species, namely M. equidens (Dana, 1852), M. jaroense (Cowles, 1914), M. latidactylus (Thallwitz, 1891), M. latimanus (von Martens, 1868) and M. placidulum (de Man, 1892). Similarly, Angre et al. (1998) described three species which are referred to the "M. equidens complex".

\section{Acknowledgements}

Thanks to Dr. Maria Tavano, curator of MSNG, for the loan of the holotype of M. ustulatum (Nobili, 1899). We are grateful to Yaya, Abdallah Ahmed Soilihi, Halidi Ahmed Ben Ali and to F. Hawkins from Conservation International of Madagascar for their help on Anjouan Island, Comoros. We warmly thank the Office of the Prime Minister of Rarotonga and in particular Teumere Koteka-Heather, D. Charlie and M. Mokoroa for research permits. We are grateful to G. McCormack and the Te Ipukara Society for their invaluable help on the field. From the Vanuatu Archipelago, we are grateful to D. Kalfatak for her invaluable help on the field. We extend our thanks to Mrs Rolenas Baereleo, our guide while prospecting the Jordan and Mantantas Rivers, in the Vatthe Conservation Area, NE Santo, to Mr. Boe, our guide at the Penoru, NW Santo during the Santo 2006 Biodiversity Expedition, to Richard, our guide at Peavot, NW Santo, and to Tabi Isaiah, our guide on Pentecost Island in 2010. We would like to thank the Ministry of Natural Resources, Environment and Tourism, Koror, Republic of Palau, and especially Helena Rebelkuul from the Bureau of Marine Resources and Kashgar Rengulbai (and his assistant Gwen) from the Bureau of Agriculture (BOAGRI), for their help with processing the research permits, setting up logistics in the field and for introducing us to the biodiversity of Palau and Babeldaob in particular. Kashgar Rengulbai also facilitated the organization of various meetings with a number of local stakeholders, including Dr Yimnang Golbuu from the Palau International Coral Reef Centre, and staff at the Environmental Quality Protection Board, the Palau Conservation Society, the Coral Reef Research Foundation and The Nature Conservancy. We are grateful to the BOAGRI staff, who 
accompanied us on the Nergmeskang River. For their helpful presence in the field, we warmly thank Philippe Gerbeaux (Department Of Conservation, New Zealand), Ahmed Abdou, Clara Lord, Pierre Feutry and Laura Taillebois (MNHN).

\section{References}

Castelin M., Feutry P., Hautecoeur M., Marquet G., Wowor D., Zimmermann G. \& Keith P. 2013. New insight on population genetic connectivity of widespread amphidromous prawn Macrobrachium lar (Fabricius, 1798) (Crustacea: Decapoda: Palaemonidae). Marine Biology 160 (6): 1395-1406. https:// doi.org/10.1007/s00227-013-2191-y

Castresana J. 2000. Selection of conserved blocks from multiple alignments for their use in phylogenetic analysis. Molecular Biology and Evolution 17: 540-552. Available from http://molevol.cmima.csic.es/ castresana/Gblocks_server.html [accessed 9 Feb. 2017].

Chace F.A.J. \& Bruce A.J. 1993. The caridean shrimps (Crustacea: Decapoda) of the Albatross Philippine Expedition, 1907-1910, Part VI. Superfamily Palaemonoidea. Smithsonian Contributions to Zoology 292: 1-152. https://doi.org/10.5479/si.00810282.543

Chen P.C., Tzeng T.D., Shih C.H., Chu T.J. \& Lee Y.C. 2015. Morphometric variation of the oriental river prawn (Macrobrachium nipponense) in Taiwan. Limnologica - Ecology and Management of Inland Waters 52: 51-58. https://doi.org/10.1016/j.limno.2015.03.002

Coleman C.O. 2003. "Digital inking": how to make perfect line drawings on computers. Organisms Diversity and Evolution 3: 1-14. https://doi.org/10.1078/1439-6092-00081

Coleman C.O. 2006. Substituting time-consuming pencil drawings in arthropod taxonomy using stacks of digital photographs. Zootaxa 1360: 61-68. Available from http://senckenberg.de/odes/03-14.htm [accessed 9 Feb. 2017].

Darriba D., Taboada G.L., Doallo R. \& Posada D. 2012. jModelTest 2: more models, new heuristics and parallel computing. Nature Methods 9: 772-772. https://doi.org/10.1038/nmeth.2109

De Grave S. \& Fransen C. 2011. Carideorum catalogus: the recent species of the dendrobranchiate, stenopodidean, procarididean and caridean shrimps (Crustacea: Decapoda). Zoologische Mededelingen Leiden 85: 195-589.

De Man J.G. 1887. Bericht über die von Herrn Dr J. Brock im indischen Archipel gesammelten Decapoden und Stomatopoden. Archiv für Naturgeschichte 53: 215-600. https://doi.org/10.5962/bhl. part. 4747

De Man J.G. 1892. Decapoden des Indischen Archipels. In: Weber M. (ed.) Zoologische Ergebnisse einer Reise in Niederländisch Ost-Indien: 265-527. E. J. Brill, Leiden, the Netherlands. https://doi. org/10.5962/bhl.title. 10298

De Man J.G. 1893. Report on the Podophthalmous Crustacea, collected in the year 1891 by Dr H. Ten Kate in some islands of the Malay Archipelago. Notes from the Leyden Museum 15: 284-310.

De Man J.G. 1902. Die von Herrn Professor Kükenthal in indischen Archipel gesammelten Dekapoden und Stomatopoden. In: Kükenthal W. (ed.) Ergebnisse einer zoologischen Forschungsreise in den Molukken und Borneo: im Auftrage der Senckenbergischen Naturforschenden Gesellschaft: 467-929. Abhandlungen der Senckenbergischen Naturforschenden Gesellschaft, Frankfurt am Main. https://doi. org/10.5962/bhl.title.10409

De Man J.G. 1915. Zur Fauna von Nord-Neuguinea. Nach den Sammlungen von Dr. P.N. van Kampen und K. Gjellerup in den Jahren 1910-1911. Macrura. Zoologische Jahrbücher-Abteilung für Systematik, Geographie und Biologie der Thiere 38: 385-458. 
Drummond A.J., Suchard M.A., Xie D. \& Rambaut A. 2012. Bayesian phylogenetics with BEAUti and the BEAST 1.7. Molecular Biology and Evolution 29: 1969-1973. https://doi.org/10.1093/molbev/ $\underline{\operatorname{mss} 075}$

Edgar R.C. 2004. MUSCLE: multiple sequence alignment with high accuracy and high throughput. Nucleic Acids Research 32: 1792-1797. https://doi.org/10.1093/nar/gkh340

Felsenstein J. 1985. Confidence limits on phylogenies: an approach using the bootstrap. Evolution 39: 783-791. https://doi.org/10.2307/2408678

Hassouna M., Michot B. \& Bachellerie J.P. 1984. The complete nucleotide sequence of mouse 28S rRNA gene. Implications for the process of size increase of the large subunit rRNA in higher eukaryotes. Nucleic Acids Research 12: 3563-3583. https://doi.org/10.1093/nar/12.8.3563

Holthuis L.B. 1950. The Palaemonidae collected by the Siboga and Snellius Expeditions, with remarks on other species. In: The Decapoda of the Siboga Expedition, II. Siboga Expedition 39a': 1-268. SibogaExpeditie, Leiden.

Huelsenbeck J.P. \& Rannala B. 2004. Frequentist properties of Bayesian posterior probabilities of phylogenetic trees under simple and complex substitution models. Systematic Biology 53: 904-913. https://doi.org/10.1080/10635150490522629

Ito A., Fujita Y. \& Shokita S. 2002. Larval stages of Macrobrachium australe (Guérin Méneville, 1838) (Decapoda: Palaemonidae), described from laboratory-reared material. Crustacean Research 31: 47-72. http://ci.nii.ac.jp/naid/110002694496/

Jayachandran K. 2001. Palaemonid prawns: biodiversity, taxonomy, biology and management. Aquaculture International 9 (6): 545-548. https://doi.org/10.1023/A:1020581119018

Jovelin R. \& Justine J.L. 2001. Phylogenetic relationships within the Polyopisthocotylean monogeneans (Plathyhelminthes) inferred from partial 28S rDNA sequences. International Journal for Parasitology 31: 393-401. https://doi.org/10.1016/S0020-7519(01)00114-X

Keith P. 2003. Biology and ecology of amphidromous Gobiidae of the Indo-Pacific and the Caribbean regions. Journal of Fish Biology 63: 831-847. https://doi.org/10.1046/j.1095-8649.2003.00197.x

Keith P., Marquet G., Gerbeaux P., Vigneux E. \& Lord C. 2013. Poissons et Crustacés d'Eau douce de Polynésie. Société francaise d'Ichthyologie, Paris.

Librado P. \& Rozas J. 2009. DnaSP v5: a software for comprehensive analysis of DNA polymorphism data. Bioinformatics 25: 1451-1452. https://doi.org/10.1093/bioinformatics/btp187

Liu M.Y., Cai Y.X. \& Tzeng C.S. 2007. Molecular systematics of the freshwater prawn genus Macrobrachium Bate, 1868 (Crustacea: Decapoda: Palaemonidae) inferred from mtDNA sequences, with emphasis on East Asian species. Zoological Studies 46: 272-289.

Miller M.A., Pfeiffer W. \& Schwartz T. 2011. The CIPRES science gateway: a community resource for phylogenetic analyses. In: Towns J. (ed.) Proceedings of the 2011 TeraGrid Conference: Extreme Digital Discovery: 1-8. Association for Computing Machinery, Salt Lake City, Utah. https://doi. org/10.1145/2016741.2016785

Nobili G. 1899. Contribuzioni alla conoscenza della fauna carcinologica della Papuasia, delle Molucche e dell'Australia. Annali del Museo civico di Storia naturale di Genova, Series 220 (40): 230-282.

Palumbi S.R. 1996. Nucleic acids II: the polymerase chain reaction. In: Hillis D.M., Mable B.K. \& Moritz C. (eds) Molecular Systematics: 205-247. Sinauer Associates, Sunderland, MA.

Palumbi S.R., Martin A., Romano S., McMillan W.O., Stice L. \& Grabowski G. 1991. The Simple Fool's Guide to PCR. Version 2. University of Hawaii, Honolulu, HI. 
Rambaut A., Suchard M., Xie D. \& Drummond A. 2014. Tracer v1.6. Available from http://beast.bio. ed.ac.uk/Tracer [accessed 10 Feb. 2017].

Richters F. 1880. Decapoda. In: von Möbius K., Richters F. \& von Martens E. (eds) Beiträge zur Meeresfauna der Insel Mauritius und der Seychellen, bearbeitet von K. Möbius, F. Richters und E. von Martens: 137-178. Verlag der Gutmann'schen Buchhandlung (Otto Enslin), Berlin.

Roux J. 1933. Crustacés décapodes d'eau douce. In: von Straelen V. (ed.) Résultats scientifiques du Voyage aux Indes Orientales Néerlandaises de LL. AA. RR. le Prince et la Princesse Léopold de Belgique: 1-19. Mémoires du Musée royal d'Histoire naturelle de Belgique, Brussels.

Short J. 2004. A revision of Australian river prawns, Macrobrachium (Crustacea: Decapoda: Palaemonidae). Hydrobiologia 525: 1-100. https://doi.org/10.1023/B:HYDR.0000038871.50730.95

Spence Bate C. 1868. On a new genus, with four new species, of freshwater prawns. Proceedings of the Zoological Society of London 1868: 363-368.

Stamatakis A. 2006. RAxML-VI-HPC: maximum likelihood-based phylogenetic analyses with thousands of taxa and mixed models. Bioinformatics 22: 2688-2690. https://doi.org/10.1093/bioinformatics/btl446

Stamatakis A., Hoover P. \& Rougemont J. 2008. A rapid bootstrap algorithm for the RAxML web servers. Systematic Biology 57: 758-771. https://doi.org/10.1080/10635150802429642

Torres M.V., Giri F. \& Collins P.A. 2014. Geometric morphometric analysis of the freshwater prawn Macrobrachium borellii (Decapoda: Palaemonidae) at a microgeographical scale in a floodplain system. Ecological Research 29: 959-968. https://doi.org/10.1007/s11284-014-1184-8

Wowor D., Muthu V., Meier R., Balke M., Cai Y. \& Ng P.K.L. 2009. Evolution of life history traits in Asian freshwater prawns of the genus Macrobrachium (Crustacea: Decapoda: Palaemonidae) based on multilocus molecular phylogenetic analysis. Molecular Phylogenetics and Evolution 52: 340-350. https://doi.org/10.1016/j.ympev.2009.01.002

Zhang Z., Schwartz S., Wagner L. \& Miller W. 2000. A greedy algorithm for aligning DNA sequences. Journal of Computational Biology 7: 203-214. https://doi.org/10.1089/10665270050081478

Zimmermann G., Bosc P., Valade P., Cornette R., Améziane N. \& Debat V. 2012. Geometric morphometrics of carapace of Macrobrachium australe (Crustacea: Palaemonidae) from Reunion Island. Acta Zoologica 93: 492-500. https://doi.org/10.1111/j.1463-6395.2011.00524.x

Manuscript received: 1 February 2016

Manuscript accepted: 6 December 2016

Published on: 1 March 2017

Guest editors: Line Le Gall, Frédéric Delsuc, Stéphane Hourdez, Guillaume Lecointre

and Jean-Yves Rasplus

Desk editor: Danny Eibye-Jacobsen

Printed versions of all papers are also deposited in the libraries of the institutes that are members of the EJT consortium: Muséum national d'Histoire naturelle, Paris, France; Botanic Garden Meise, Belgium; Royal Museum for Central Africa, Tervuren, Belgium; Natural History Museum, London, United Kingdom; Royal Belgian Institute of Natural Sciences, Brussels, Belgium; Natural History Museum of Denmark, Copenhagen, Denmark; Naturalis Biodiversity Center, Leiden, the Netherlands. 
Appendix. List of the 28S and 16S rRNA sequences recovered from GenBank. 28S $=28 \mathrm{~S}$ rRNA GenBank accession number; 16S = 16S rRNA GenBank accession number.

\begin{tabular}{|c|c|c|c|c|}
\hline Species & Locality & $28 \mathrm{~S}$ & $16 S$ & Source \\
\hline \multirow{4}{*}{$\begin{array}{c}\text { M. asperulum } \\
\text { (von Martens, 1868) }\end{array}$} & Taiwan & - & AB250423 & Liu et al. 2011 \\
\hline & Taiwan & - & AB250424 & Liu et al. 2011 \\
\hline & Taiwan & - & AB250433 & Liu et al. 2011 \\
\hline & Taiwan & - & AB250459 & Liu et al. 2011 \\
\hline \multirow[t]{2}{*}{ M. australiense Holthuis, 1950} & Australia & AY374145 & - & Murphy \& Austin 2005 \\
\hline & Australia & - & EF588317 & Page et al. 2008a \\
\hline M. brasiliense (Heller, 1862) & Brazil & AY374146 & - & Murphy and Austin 2005 \\
\hline M. bullatum Fincham, 1987 & Australia & AY374147 & - & Murphy and Austin 2005 \\
\hline M. callirrhoe (de Man, 1898) & Sumatra & FM955490 & - & Wowor et al. 2009 \\
\hline M. crenulatum Holthuis, 1950 & Venezuela & - & GU929465 & Vergamini et al. 2011 \\
\hline M. dux (Lenz, 1910) & Nigeria & - & KJ463388 & Unpubl. \\
\hline $\begin{array}{c}\text { M. edentatum } \\
\text { Liang \& Yan, } 1986\end{array}$ & China & - & DQ194912 & Liu et al. 2007 \\
\hline \multirow[t]{4}{*}{ M. equidens (Dana, 1852) } & Taiwan & EU493126 & - & Chen et al. 2009 \\
\hline & Taiwan & EU493128 & - & Chen et al. 2009 \\
\hline & Taiwan & EU493129 & - & Chen et al. 2009 \\
\hline & Taiwan & EU493130 & - & Chen et al. 2009 \\
\hline \multirow[t]{5}{*}{ M. esculentum (Thallwitz, 1891) } & Taiwan & EU008722 & - & Chen et al. 2009 \\
\hline & Taiwan & EU493113 & EU493145 & Chen et al. 2009 \\
\hline & Taiwan & - & DQ194913 & Liu et al. 2007 \\
\hline & Philippines & - & DQ194914 & Liu et al. 2007 \\
\hline & S Sulawesi & FM955498 & - & Wowor et al. 2009 \\
\hline $\begin{array}{c}\text { M. faustinum } \\
\text { (de Saussure, 1857) }\end{array}$ & Puerto Rico & - & EF490009 & Page et al. 2008b \\
\hline \multirow{6}{*}{$\begin{array}{c}\text { M. formosense } \\
\text { Spence Bate, } 1868\end{array}$} & Taiwan & EU008723 & - & Chen et al. 2009 \\
\hline & Taiwan & EU493104 & - & Chen et al. 2009 \\
\hline & Taiwan & EU493106 & - & Chen et al. 2009 \\
\hline & Taiwan & EU493111 & - & Chen et al. 2009 \\
\hline & Taiwan & EU493131 & - & Chen et al. 2009 \\
\hline & Japan & FM955489 & - & Wowor et al. 2009 \\
\hline M. gracilirostre (Miers, 1875) & N Sulawesi & - & FM986613 & Wowor et al. 2009 \\
\hline M. hainanense (Parisi, 1919) & Hainan & FM955502 & - & Wowor et al. 2009 \\
\hline $\begin{array}{l}\text { M. heterochirus } \\
\text { (Wiegmann, 1836) }\end{array}$ & Brazil & - & HM352454 & Pileggi \& Mantelatto 2010 \\
\hline $\begin{array}{c}\text { M. holthuisi } \\
\text { Genofre \& Lobão, } 1978\end{array}$ & Brazil & - & HM352456 & Pileggi \& Mantelatto 2010 \\
\hline M. horstii (de Man, 1892) & Borneo & - & FM986616 & Wowor et al. 2009 \\
\hline M. idae (Heller, 1862) & Tioman Island & - & FM986617 & Wowor et al. 2009 \\
\hline \multirow{3}{*}{$\begin{array}{l}\text { M. japonicum (De Haan, } 1849 \text { in } \\
\text { De Haan 1833-1850) }\end{array}$} & Taiwan & EU008721 & - & Chen et al. 2009 \\
\hline & Taiwan & - & - & Chen et al. 2009 \\
\hline & Taiwan & EU493110 & - & Chen et al. 2009 \\
\hline
\end{tabular}




\begin{tabular}{|c|c|c|c|c|}
\hline Species & Locality & $28 \mathrm{~S}$ & $16 S$ & Source \\
\hline M. lanatum Cai \& Ng, 2002 & Sumatra & - & FM986639 & Wowor et al. 2009 \\
\hline \multirow[t]{5}{*}{ M. lar (Fabricius, 1798) } & Cook Island & KC507005 & KC506861 & Castelin et al. 2013 \\
\hline & Cook Island & KC507006 & KC506865 & Castelin et al. 2013 \\
\hline & Cook Island & KC507007 & KC506866 & Castelin et al. 2013 \\
\hline & Cook Island & KC507011 & - & Castelin et al. 2013 \\
\hline & Cook Island & KC507012 & KC506871 & Castelin et al. 2013 \\
\hline \multirow[t]{2}{*}{ M. latidactylus (Thallwitz, 1891) } & Philippines & - & DQ194945 & Liu et al. 2007 \\
\hline & Thailand & - & DQ194946 & Liu et al. 2007 \\
\hline \multirow{9}{*}{$\begin{array}{c}\text { M. latimanus } \\
\text { (von Martens, 1868) }\end{array}$} & Taiwan & EU008729 & - & Chen et al. 2009 \\
\hline & Taiwan & EU493112 & - & Chen et al. 2009 \\
\hline & Taiwan & EU493114 & - & Chen et al. 2009 \\
\hline & Taiwan & - & DQ194936 & Liu et al. 2007 \\
\hline & Philippines & - & DQ194937 & Liu et al. 2007 \\
\hline & Japan & - & DQ194938 & Liu et al. 2007 \\
\hline & India & - & JF774070 & Unpubl. \\
\hline & West Java & FM955511 & - & Wowor et al. 2009 \\
\hline & $\begin{array}{l}\text { Bt. Ciawi Tali, } \\
\text { W Java or } \\
\text { Lanyu }\end{array}$ & FM955512 & - & Wowor et al. 2009 \\
\hline \multirow{4}{*}{$\begin{array}{l}\text { M. lepidactyloides } \\
\text { (de Man, 1892) }\end{array}$} & Taiwan & EU008725 & - & Chen et al. 2009 \\
\hline & Taiwan & EU493115 & - & Chen et al. 2009 \\
\hline & Taiwan & EU493116 & - & Chen et al. 2009 \\
\hline & Taiwan & EU493118 & - & Chen et al. 2009 \\
\hline \multirow[t]{2}{*}{ M. malayanum (Roux, 1935) } & Singapore & AY374157 & - & Murphy \& Austin 2005 \\
\hline & Nee Soon & FM955515 & - & Wowor et al. 2009 \\
\hline \multirow{2}{*}{$\begin{array}{l}\text { M. mammillodactylus } \\
\text { (Thallwitz, 1892) }\end{array}$} & Taiwan & - & EU493148 & Chen et al. 2009 \\
\hline & East Kalimantan & - & FM986629 & Wowor et al. 2009 \\
\hline \multirow{3}{*}{$\begin{array}{c}\text { M. meridionale } \\
\text { Liang \& Yan, } 1983\end{array}$} & China & - & DQ194948 & Liu et al. 2007 \\
\hline & Malaysia & - & DQ194949 & Liu et al. 2007 \\
\hline & Hong Kong & FM955518 & - & Wowor et al. 2009 \\
\hline M. neglectum (de Man, 1905) & Malaysia & - & DQ194953 & Liu et al. 2007 \\
\hline \multirow{4}{*}{$\begin{array}{l}\text { M. niphanae } \\
\text { Shokita \& Takeda, } 1989\end{array}$} & Thailand & - & JQ359750 & Pinpart et al. 2010 \\
\hline & Thailand & - & JQ359752 & Pinpart et al. 2010 \\
\hline & Thailand & - & JQ390472 & Pinpart et al. 2010 \\
\hline & Thailand & - & JQ390473 & Pinpart et al. 2010 \\
\hline \multirow{4}{*}{$\begin{array}{l}\text { M. nipponense (De Haan, } 1849 \\
\text { in De Haan 1833-1850) }\end{array}$} & Taiwan & EU493119 & - & Chen et al. 2009 \\
\hline & Taiwan & EU493120 & - & Chen et al. 2009 \\
\hline & Taiwan & EU493123 & - & Chen et al. 2009 \\
\hline & Yizhang, Hunan & FM955520 & - & Wowor et al. 2009 \\
\hline \multirow[t]{2}{*}{ M. ohione (Smith, 1874) } & Gulf of Mexico & EU868694 & EU868694 & Bracken et al. 2009 \\
\hline & Louisiana & - & HM352464 & Pileggi \& Mantelatto 2010 \\
\hline
\end{tabular}


CASTELIN M. et al., Evidence for cryptic species in Macrobrachium australe

\begin{tabular}{|c|c|c|c|c|}
\hline Species & Locality & $28 \mathrm{~S}$ & $16 S$ & Source \\
\hline \multirow[t]{4}{*}{ M. olfersii (Wiegmann, 1836) } & Brazil & - & EF588321 & Murphy \& Austin 2005 \\
\hline & Brazil & AY374159 & - & Murphy \& Austin 2005 \\
\hline & Brazil & - & HM352457 & Pileggi \& Mantelatto 2010 \\
\hline & Venezuela & - & HM352460 & Pileggi \& Mantelatto 2010 \\
\hline \multirow[t]{3}{*}{ M. pilimanus (de Man, 1879) } & $\begin{array}{l}\text { Central Indo- } \\
\text { Pacific }\end{array}$ & GQ487513 & - & Bracken et al. 2010 \\
\hline & Khammouane & FM955492 & - & Wowor et al. 2009 \\
\hline & Khammouane & FM955521 & - & Wowor et al. 2009 \\
\hline M. placidum (de Man, 1892) & Sumatra & - & FM986636 & Wowor et al. 2009 \\
\hline M. platycheles Ou \& Yeo, 1995 & Singapore & AY374161 & - & Murphy \& Austin 2005 \\
\hline M. potuina (Müller, 1880) & Brazil & AY374162 & - & Murphy \& Austin 2005 \\
\hline M. risembergii (de Man, 1879) & Tonle Sap & FM955495 & - & Wowor et al. 2009 \\
\hline \multirow[t]{3}{*}{ M. rosenbergii (de Man, 1879) } & Australia & AY374144 & - & Murphy \& Austin 2005 \\
\hline & Thailand & AY374163 & - & Murphy \& Austin 2005 \\
\hline & Irian Jaya & FM955524 & - & Wowor et al. 2009 \\
\hline M. saigonense Nguyên, 2006 & Tonle Sap & FM955525 & - & Wowor et al. 2009 \\
\hline \multirow[t]{2}{*}{ M. shokitai Fujino \& Baba, 1973} & Ryukyus, Japan & - & AB250466 & Liu et al. 2007 \\
\hline & Japan & - & DQ194961 & Liu et al. 2007 \\
\hline M. sintangense (de Man, 1898) & Thailand & FM955528 & - & Wowor et al. 2009 \\
\hline \multirow[t]{2}{*}{ M. trompii (de Man, 1898) } & Sumatra & FM955529 & - & Wowor et al. 2009 \\
\hline & Sumatra & - & FM986642 & Wowor et al. 2009 \\
\hline $\begin{array}{c}\text { M. urayang } \\
\text { Wowor \& Short, } 2007\end{array}$ & E Kalimantan & FM955530 & - & Wowor et al. 2009 \\
\hline \multirow[t]{10}{*}{ M. ustulatum (Nobili, 1899) } & Taiwan & EU008719 & - & Chen et al. 2009 \\
\hline & Taiwan & - & EU493135 & Chen et al. 2009 \\
\hline & Taiwan & EU493097 & - & Chen et al. 2009 \\
\hline & Taiwan & EU493098 & - & Chen et al. 2009 \\
\hline & Taiwan & EU518931 & - & Chen et al. 2009 \\
\hline & Taiwan & - & DQ194904 & Liu et al. 2007 \\
\hline & Philippines & - & DQ194905 & Liu et al. 2007 \\
\hline & $\begin{array}{l}\text { Papua New } \\
\text { Guinea }\end{array}$ & - & JF310710 & Page \& Hughes 2011 \\
\hline & New Guinea & - & DQ681290 & Page et al. 2007 \\
\hline & $\begin{array}{l}\text { Papua New } \\
\text { Guinea }\end{array}$ & FN995633 & - & Page \& Hughes 2011 \\
\hline $\begin{array}{l}\text { M. vollenhovenii } \\
\text { (Herklots, 1857) }\end{array}$ & Nigeria & - & KJ463387 & Unpubl. \\
\hline \multirow[t]{2}{*}{ P. debilis Dana, 1852} & China & - & KC515044 & Kou et al. 2013 \\
\hline & Sumatra & FM955535 & - & Wowor et al. 2009 \\
\hline
\end{tabular}




\section{References for Appendix}

Bracken H.D., De Grave S. \& Felder D.L. 2009. Phylogeny of the infraorder Caridea based on mitochondrial and nuclear genes (Crustacea: Decapoda). In: Martin J.W., Crandall K.A. \& Felder D.L. (eds) Decapod Crustacean Phylogenetics: 281-305. CRC Press, Boca Raton, FL. https://doi. org/10.1201/9781420092592-c14

Bracken H.D., De Grave S., Toon A., Felder D.L. \& Crandall K.A. 2010. Phylogenetic position, systematic status, and divergence time of the Procarididea (Crustacea: Decapoda). Zoologica Scripta 39: 198-212. https://doi.org/10.1111/j.1463-6409.2009.00410.x

Castelin M., Feutry P., Hautecoeur M., Marquet G., Wowor D., Zimmermann G. \& Keith P. 2013. New insight on population genetic connectivity of widespread amphidromous prawn Macrobrachium lar (Fabricius, 1798) (Crustacea: Decapoda: Palaemonidae). Marine Biology 160 (6): 1395-1406. https:// doi.org/10.1007/s00227-013-2191-y

Chen R.T., Tsai C.F. \& Tseng W.N. 2009. Freshwater prawns (Macrobrachium Bate, 1868) of Taiwan with special references to their biogeographical origins and dispersion routes. Journal of Crustacean Biology 29 (2): 232-244. https://doi.org/10.1651/08-3072.1

Kou Q., Li X., Chan T.Y., Chu K.H, Huang H. \& Zhibin G. 2013. Phylogenetic relationships among genera of the Periclimines complex (Crustacea: Decapoda: Pontoniidae) based on mitochondrial and nuclear DNA. Molecular Phylogenetics and Evolution 68: 14-22. https://doi.org/10.1016/j.ympev.2013.03.010

Liu M.Y., Cai Y.X. \& Tzeng C.S. 2007. Molecular systematics of the freshwater prawn genus Macrobrachium Bate, 1868 (Crustacea: Decapoda: Palaemonidae) inferred from mtDNA sequences, with emphasis on East Asian species. Zoological Studies 46: 272-289.

Liu M.Y., Tzeng C.S. \& Lin H.D. 2011. Phylogeography and the genetic structure of the landlocked freshwater prawn Macrobrachium asperulum (Crustacea: Decapoda: Palaemonidae) in Taiwan. Hydrobiologia 671 (1): 1-12. https://doi.org/10.1007/s10750-011-0699-Z

Murphy N.P. \& Austin C.M. 2005. Phylogenetic relations of the globally distributed freshwater prawn genus Macrobrachium (Crustacea: Decapoda: Palaemonidae): biogeography, taxonomy and the convergent evolution of abbreviated larval development. Zoologica Scripta 34 (2): 187-197. https://doi. org/10.1111/j.1463-6409.2005.00185.x

Page T.J. \& Hughes J.M. 2011. Neither molecular nor morphological data have all the answers with an example from Macrobrachium (Decapoda; Palaemonidae) from Australia. Zootaxa 2874: 65-68.

Page T.J, von Rintelen K. \& Hughes J.M. 2007. Phylogenetic and biogeographic relationships of subterranean and surface genera of Australian Atyidae (Crustacea: Decapoda: Caridea) inferred with mitochondrial DNA. Invertebrate Systematics 21: 137-145. https://doi.org/10.1071/IS06023

Page T.J., Short J.W., Humphrey C.L, Hillyer M.J \& Hughes J.M. 2008a. Molecular systematics of the Kakaducarididae (Crustacea: Decapoda: Caridea). Molecular Phylogenetics and Evolution 46: 10031014. https://doi.org/10.1016/j.ympev.2007.12.020

Page T.J., Cook B.D., von Rintelen T., von Rintelen K. \& Hughes J.M. 2008b. Evolutionary relationships of atyid shrimps imply both ancient Caribbean radiations and common marine dispersals. Journal of the North American Benthological Society 27: 68-83. https://doi.org/10.1899/07-044R.1

Pileggi L.G. \& Mantelatto F.L. 2010. Molecular phylogeny of the freshwater prawn genus Macrobrachium (Decapoda, Palaemonidae), with emphasis on the relationships of selected American species. Invertebrate Systematics 24: 194-208. https://doi.org/10.1071/IS09043 
Pinpart T., Sangthong P. \& Ngernsiri L. 2010. Sequence Divergence of Mitochondrial DNA among Freshwater Genus Macrobrachium in Basins of the Central, Western and Eastern Parts of Thailand. Unpublished.

Vergamini F.G., Pileggi L.G. \& Mantelatto F.L. 2011. Genetic variability of the Amazon river prawn Macrobrachium amazonicum (Decapoda, Caridea, Palaemonidae). Contributions to Zoology 80 (1): $67-83$

Wowor D., Muthu V., Meier R., Balke M., Cai Y. \& Ng P.K.L. 2009. Evolution of life history traits in Asian freshwater prawns of the genus Macrobrachium (Crustacea: Decapoda: Palaemonidae) based on multilocus molecular phylogenetic analysis. Molecular Phylogenetics and Evolution 52: 340-350. https://doi.org/10.1016/j.ympev.2009.01.002 